„Analecta Cracoviensia” 50 (2018), s. 125-160

DOI: http://dx.doi.org/10.15633/acr.3286

Beata Stypułkowska

Wyższy Instytut Teologiczny, Częstochowa

\title{
Pustelnicy jako przedstawiciele indywidualnej formy życia konsekrowanego
}

\section{Uwagi wstępne}

Życie pustelnicze rozwinęło się w IV wieku. U podłoża formowania się tego sposobu życia tkwiła idea pełnego naśladowania Chrystusa. Bardzo wyraźnie wskazują na nią autorzy żywotów pustelników czy kompilatorzy apoftegmatów ojców pustyni ${ }^{1}$. Słowa Chrystusa o porzuceniu wszystkiego, aby pójść za Nim², skłaniały mężczyzn i kobiety do zerwania ze światem. W Egipcie powstawały wielkie typowe formy instytucji monastycznej. Tam żyli ojcowie pustyni stanowiący dla niej wzór, jak św. Antoni, który za swojego życia wywierał poważny wpływ na innych pustelników. Jego żywot napisany po grecku przez św. Atanazego, przetłumaczony również na łacinę, zyskał wielką popularność, przyczynił się do lepszego poznania życia pustelniczego ${ }^{3}$ i dla wielu osób stał się zachętą do naśladowania ${ }^{4}$. Forma monastycznego życia, ustanowiona przez Antoniego, stała się wzorem dla pustelnika, który zrywa

Por. T. Kaczmarek, Ideały życia pustelniczego w IV wieku, w: Wczesnochrześcijańska asceza. Zagadnienia wybrane, red. F. Drączkowski, J. Pałucki, Lublin 1993, s. 62.

2 Zob. Mk 10, 21; Mt 19, 21; Łk 18, 22.

3 Św. Atanazy Aleksandryjski, Żywot świętego Antoniego, w: Św. Atanazy Aleksandryjski, Żywot świętego Antoniego, Św. Antoni Pustelnik, Pisma, przeł. Z. Brzostowska i in., wstępami i komentarzami opatrzyła E. Wipszycka, Warszawa 1987, s. 55-111.

4 Por. J. Grzywaczewski, Porozmawiajmy o początkach chrześcijaństwa, Warszawa 1999, s. 287. 
kontakt z ludźmi i pragnie prowadzić dialog sam na sam z Bogiem. Święty Antoni, zerwawszy wszelkie związki ze światem, oddaje się życiu samotne$\mathrm{mu}$, w którym dużą rolę odgrywa pokuta i surowa asceza ${ }^{6}$. Na pustyni żył również św. Pachomiusz, twórca klasztorów’, w których wiedli żywot mnisi oddzieleni od świata.

Oczywiście, nie zawsze mamy pewność, czy w przekazach źródłowych chodzi o pustelników czy o mnichów. W źródłach greckich i koptyjskich zarówno erem, jak i klasztor są określane terminem monasteria. Święty Antoni żył w monasterion, ale wspólnoty pachomiańskie też były tak określane ${ }^{8}$. W opracowaniach niejednokrotnie używa się zamiennie słów „mnich” i „pustelnik”. Termin „mnich” (gr. monachos - pojedynczy) stosowany jest przez św. Atanazego Wielkiego w odniesieniu do św. Antoniego, po rozpoczęciu przezeń życia na pustyni. W Kościele łacińskim od IV wieku słowo to było używane na określenie: anachorety (gr. anachoreto - oddalam się) albo eremity (gr. eremos - pustynia); continentes, czyli wstrzemięźliwych - dziewic i ascetów, zachowujących czystość i celibat, żyjących samotnie lub w małych grupach; cenobity (gr. koinobion - życie we wspólnocie), żyjącego z innymi na wzór gminy jerozolimskiej; mnicha pachomiańskiego; osoby scalonej wewnętrznie, osiągającej jedność wewnętrzną przez zjednoczenie z Bogiem; w średniowieczu także członka mniszego zakonu. To ostatnie znaczenie przyjmowane jest współcześnie ${ }^{9}$.

Niniejszy artykuł jest trzecim z kolei artykułem podejmującym zagadnienie indywidualnych form życia konsekrowanego. Pierwszy artykuł zainspirowany listem apostolskim papieża Franciszka Świadkowie radości ogłoszonym w roku życia konsekrowanego dotyczył w sposób ogólny wszystkich przedstawicieli indywidualnych form życia konsekrowanego, a mianowicie: dziewic, wdów i pustelników. Było to spojrzenie na poszczególne formy z perspektywy

5 Por. [H.] Daniel-Rops, Kościół pierwszych wieków, przeł. K. Ostrowska, Warszawa 1997, S. 523 .

6 Por. J. Daniélou, H. I. Marrou, Historia Kościoła, t. 1: Od początków do roku 6oo, przeł. M. Tarnowska, Warszawa 1984, s. 211.

7 Por. [H.] Daniel-Rops, Kościót pierwszych wieków, dz. cyt., s. 522.

8 Por. E. Wipszycka, R. Wiśniewski, Wstęp, w: Historia mnichów w Egipcie, przekł. E. Dąbrowska, Kraków-Tyniec 2011, s. 10.

Por. M. Daniluk, K. Klauza, Podręczna encyklopedia instytutów życia konsekrowanego, Lublin 1994, s. 197-198; M. Starowieyski, Wstęp, w: Pierwsza Księga Starców. Gerontikon, przekł. M. Borkowska, wstęp, opracowanie i redakcja M. Starowieyski, Kraków 1992, s. 13. 
przeszłości, teraźniejszości i przyszłości ${ }^{10}$. Drugi artykuł dotyczył stanu dziewic, a w sposób szczegółowy ukazał perspektywy wynikające z duchowości monastycznej ${ }^{11}$.

Niniejszy artykuł podejmuje zagadnienie pustelników jako przedstawicieli indywidualnej formy życia konsekrowanego. Opiera się na dostępnych źródłach dotyczących życia pustelniczego, zwłaszcza w jego okresie początkowym, oraz na opracowaniach. Starano się dotrzeć do reguł życia współczesnych pustelników, co niestety było bardzo trudne. Obecnie różne osoby określają siebie pustelnikami. Postawiono pytania odnoszące się do różnic i podobieństw między życiem pustelników a życiem dziewic i wdów, specyfiki życia pustelniczego, duchowości pustelników. W pojedynczych przypadkach sposób życia pustelników może być różny. Celem artykułu nie jest formułowanie wytycznych dla pustelników, ale postawienie pytań i zainicjowanie wymiany poglądów odnoszących się do zachowania specyfiki indywidualnej formy życia konsekrowanego.

\section{Indywidualne formy życia konsekrowanego}

Eremityzm, zwany obecnie także diecezjalnym życiem pustelniczym, jest obok stanu dziewic i stanu wdów indywidualną formą życia konsekrowanego ${ }^{12}$. Indywidualne formy życia konsekrowanego polegają na realizacji własnego charyzmatu w ramach Kościoła diecezjalnego w bezpośrednim posłuszeństwie biskupowi diecezjalnemu, który rozeznaje powołanie, dopuszcza do konsekracji i troszczy się o prawidłowe życie w wybranym stanie lub powołaniu.

Jedynie pustelnicy zobowiązują się publicznie wobec biskupa diecezjalnego do praktykowania trzech rad ewangelicznych ${ }^{13}$, dzięki czemu w sensie kanonicznym są osobami życia konsekrowanego ${ }^{14}$. Kodeks prawa kanonicznego

${ }^{10}$ Por. B. Stypułkowska, Indywidualne formy życia konsekrowanego w kontekście roku życia konsekrowanego, „Częstochowskie Studia Teologiczne” 43 (2015), s. 117-145.

${ }^{11}$ Por. B. Stypułkowska, Perspektywy dla dziewic konsekrowanych żyjacych $w$ świecie wynikające $z$ duchowości monastycznej, „Analecta Cracoviensia” 48 (2016), s. 195-222.

${ }_{12}$ Por. H. Śmiarowski, Niektóre wskazania duszpasterskie dotyczące konsekrowanych pustelników i pustelnic, http://www.ifzk.episkopat.pl/dokumenty/3.4.3-ove-artykul-aneks.pdf (8.11.2016).

${ }_{13}$ Zob. Kodeks prawa kanonicznego. Przekład polski zatwierdzony przez Konferencję Episkopatu [dalej: KPK], Poznań 1984, kan. 603, \$2.

${ }^{14}$ L. Leidi, Tożsamość indywidualnych form życia konsekrowanego w Kościele, http://www. konsekrowane.org/dziewice/konf.php (22.11.2016). 
ściśle wiąże życie konsekrowane z profesją trzech rad ewangelicznych ${ }^{15}$. Przedmiotem zobowiązań pustelnika są rady ewangeliczne, tak jak w przypadku członków instytutów życia konsekrowanego, dzięki czemu pustelnicy sensu stricto są przedstawicielami jednej z form życia konsekrowanego ${ }^{16}$. Ich przełożonym pozostaje biskup diecezjalny ${ }^{17}$. Nie chodzi zatem o zakonników, którzy zgodnie z prawem własnym przez określony czas wiodą życie w odosobnieniu, nie tracąc formalnej więzi ze swoim instytutem kontemplacyjnym ${ }^{18}$.

Kodeks prawa kanonicznego, charakteryzując życie konsekrowane, mówi o trwałej formie życia ${ }^{19}$. Trwałość życia konsekrowanego polega na tym, że profesję rad ewangelicznych składa się na całe życie. Oczywiście zakłada się okres przygotowawczy, umożliwiający złożenie ślubów na określony czas, po którym śluby są ponawiane. W odniesieniu do pustelników, o których mowa w niniejszym artykule, trwałość formy życia polega na zachowywaniu właściwego trybu życia, charakterystycznego dla pustelnika, pod kierownictwem biskupa diecezjalnego. Warunki życia pustelnika mogą się zmieniać w ciągu jego życia ze względu na wiek i zdrowie.

Kodeks prawa kanonicznego wskazuje na to, że prawnie uznaje się za pustelnika osobę poświęconą Bogu w życiu konsekrowanym, jeśli poprzez ślub albo inne święte więzy zobowiązuje się publicznie wobec biskupa diecezjalnego do praktykowania trzech rad ewangelicznych i pod jego kierownictwem zachowuje właściwy tryb życia ${ }^{20}$. Zatem profesja rad ewangelicznych czyni z danej osoby człowieka poświęconego Bogu w życiu konsekrowanym, a właściwy tryb życia pod kierownictwem biskupa diecezjalnego wskazuje na to, że jest on pustelnikiem.

${ }_{15}$ Zob. кPK, kan. $573 \$ 1$. Paragraf ten brzmi następująco: „Życie konsekrowane przez profesję rad ewangelicznych jest trwałą formą życia, w której wierni pod działaniem Ducha Świętego naśladując dokładnej Chrystusa, oddają się całkowicie umiłowanemu nade wszystko Bogu, ażeby poświęceni z nowego i szczególnego tytułu dla chwały Boga, budowania Kościoła i zbawienia świata - osiągnąć doskonałą miłość w służbie Królestwa Bożego i, stawszy się w Kościele wyraźnym znakiem, zapowiadać niebieską chwałę".

${ }_{16}$ Por. A. Chrapkowski, J. Krzywda, J. Wroceński, B. W. Zubert, Komentarz do Kodeksu Prawa Kanonicznego, t. II/2: Księga II: Lud Boży. Część III: Instytuty życia konsekrowanego i stowarzyszenia życia apostolskiego, red. naukowy J. Krukowski, Poznań 2006, s. 36.

${ }_{17}$ Por. A. Chrapkowski, J. Krzywda, J. Wroceński, B. W. Zubert, Komentarz do Kodeksu Prawa Kanonicznego, t. II/2: Księga II: Lud Boży. Część III..., dz. cyt., s. 36.

${ }_{18}$ Por. B. W.Zubert, Komentarz do Kodeksu Prawa Kanonicznego z 1983 roku. Ksiega II: Lud Boży. Część III: Instytuty życia konsekrowanego i stowarzyszenia życia apostolskiego, Lublin 1990, s. 42.

19 Zob. KPK, kan. $573 \$ 1$.

${ }^{20}$ Zob. KPK, kan. $603 \$ 2$. 
W odróżnieniu od stanu dziewic i stanu wdów oraz wdowców, które zastrzeżone są dla osób spełniających określone warunki, pustelnikiem może zostać osoba świecka (mężczyzna lub kobieta) czy też kapłan diecezjalny. Nie ma przeszkód też, by pustelnikiem w pewnym okresie życia została dziewica lub wdowa. Z tego względu zarówno formacja, jak i życie pustelnicze mogą się znacznie różnić w poszczególnych przypadkach. Inne trudności przeżywa samotna kobieta, inne samotny mężczyzna. Poza tym, gdy pustelnikiem zostanie prezbiter, inaczej będzie wyglądało jego życie eucharystyczne niż pozostałych osób.

\section{Obraz życia pustelniczego oczyma}

\section{św. Atanazego Aleksandryjskiego oraz św. Hieronima}

$\dot{Z} y w o t$ św. Antoniego napisany przez św. Atanazego Aleksandryjskiego ${ }^{21}$ oraz $\dot{Z} y$ wot św. Pawła Pierwszego Pustelnika napisany przez św. Hieronima ${ }^{22}$ są dziełami poświęconymi postaciom pustelników. Dzięki tym utworom rysuje się obraz życia pustelniczego pierwszych wieków. Dzieło św. Atanazego wywarło duży wpływ na współczesnych. Stało się dla wielu niejako „regułą życia”. Natomiast dzieło św. Hieronima jest utworem młodzieńczym, ulotnym, choć pełnym uroku. 3.1. Żywot świętego Antoniego i jego oddziaływanie na innych Święty Atanazy Aleksandryjski napisał Żywot św. Antoniego między rokiem 356 a 362, na prośbę mnichów ${ }^{23}$. Prawdopodobnie już w młodości nawiązał osobiste kontakty ze św. Antonim ${ }^{24}$, a jako biskup Aleksandrii kilkakrotnie

${ }^{21}$ S. Athanasii, Vita S. Antonii, in: S.P.N. Athanasii archiepiscopi Alexandrini Opera omnia quae exstant, tomus secundus, accurante et recognoscente J.-P. Migne, Parisiis 1857, col. 835-976 (Patrologiae Cursus Completus. Series Graeca [dalej: PG], 26), http://patristica.net/graeca/\#to26 (23.12.2016); tekst polski: Św. Atanazy Aleksandryjski, Żywot świętego Antoniego, w: Św. Atanazy Aleksandryjski, Żywot świętego Antoniego, Św. Antoni Pustelnik, Pisma, dz. cyt., s. 55-111.

${ }^{22}$ S. Eusebii Hieronymi, Vita S. Pauli primi eremita, in: S. Eusebii Hieronymi Stridonensis presbyteri Opera omnia, tomi secundus et tertius, accurante J.-P. Migne, Parisiis 1845, col. 17-28 (Patrologiae Cursus Completus. Series Latina [dalej: PL], 23), http://patristica.net/latina/ (27.12.2016); tekst polski: Św. Hieronim, Żywot św. Pawła Pierwszego Pustelnika, tłum. W. Szołdrski, w: J. S. Płatek, Początki Zakonu św. Pawła Pierwszego Pustelnika. Źródła duchowości Zakonu św. Pawła Pierwszego Pustelnika, Częstochowa 1989, s. 32-41.

${ }^{23}$ Zob. Św. Atanazy Aleksandryjski, Żywot świętego Antoniego, Św. Antoni Pustelnik, Pisma, dz. cyt., s. 31.

${ }_{24}$ Por. B. Altaner, A. Stuiber, Patrologia. Życie, pisma i nauka Ojców Kościoła, przeł. P. Pachciarek, Warszawa 1990, s. 379; F. Drączkowski, Patrologia, Pelplin-Lublin 1999, s. 189; H. von Campenhausen, Ojcowie Kościoła, tłum. K. Wierszyłowski, Warszawa 1998, s. 69. 
przebywając na wygnaniu, żył w pustelniach i klasztorach egipskich ${ }^{25} . \dot{Z} y w o t$ św. Antoniego napisał właśnie wśród mnichów. Dzieło to otwiera nowy gatunek literacki, hagiografię ${ }^{26}$, według którego opracowano wiele greckich żywotów świętych ${ }^{27}$. Hagiografia obejmuje legendy o życiu i czynach świętych ${ }^{28} . \mathrm{Z}$ tym wiąże się sprawa wiarygodności informacji zawartych w Żywocie św. Antoniego. Nie wszystko, co Atanazy opowiada o Antonim, może być sprawdzone. Jednakże porównanie żywota $\mathrm{z}$ apoftegmatami czy listami daje pewien obraz o osobie św. Antoniego ${ }^{29}$.

Święty Antoni był jednym spośród wielu anachoretów. To św. Atanazy uczynił zeń odkrywcę i pierwowzór życia pustelniczego ${ }^{30}$. Żywot św. Antoniego to najważniejsze dzieło epoki wczesnego monastycyzmu, w którym przedstawiono zasady życia monastycznego ${ }^{31}$. Jest przykładem żywota-reguły czy żywota-wzoru, w sytuacji gdy żywot świętego staje się regułą dla wspólnoty ${ }^{32}$.

Żywot św. Antoniego upowszechnił życie pustelnicze w Kościele i pobudził wielu wiernych do gorliwości w tym zakresie ${ }^{33}$. W 375 roku Ewagriusz z Pontu przełożył Żywot św. Antoniego na język łaciński, co przyczyniło się w znacznym stopniu do propagowania ideału życia monastycznego na Wschodzie i Zachodzie ${ }^{34}$. Czytelnikami Żywota był i św. Grzegorz z Nazjanzu, i św. Augustyn. Grzegorz z Nazjanzu pewnie z uwagą czytał wskazówki odnoszące się do życia pustelniczego, ponieważ sam oddawał się przez pewien czas takiemu życiu razem ze św. Bazylim Wielkim i św. Grzegorzem z Nyssy w pustelni nad rzeką Irys, w Poncie. Święty Grzegorz z Nazjanzu powiedział, że św. Atanazy

${ }_{25}$ Por. F. Drączkowski, Patrologia, dz. cyt., s. 189.

26 Por. J. Sławiński, Hagiografia, w: Słownik terminów literackich, red. J. Sławiński, WrocławWarszawa 1976, s. 149; Św. Atanazy Aleksandryjski, Żywot świętego Antoniego, Św. Antoni Pustelnik, Pisma, dz. cyt., s. 32 .

${ }^{27}$ Por. H. von Campenhausen, Ojcowie Kościoła, dz. cyt., s. 69.

${ }_{28}$ Por. J. Sławiński, Hagiografia, dz. cyt., s. 149.

${ }_{29}$ Zob. Św. Atanazy Aleksandryjski, Żywot świętego Antoniego, Św. Antoni Pustelnik, Pisma, dz. cyt., s. 34 .

${ }^{30}$ Por. H. von Campenhausen, Ojcowie Kościoła, dz. cyt., s. 69.

${ }^{31}$ Por. F. Drączkowski, Patrologia, dz. cyt., s. 192.

${ }^{32}$ Por. Wstęp, w: Zachodnie reguły monastyczne, przekł. K. Bielawski i in., wstępy: J. Naumowicz i in., oprac. T. Dekert i in., red. M. Starowieyski, Tyniec-Kraków 2013, s. 34-35.

33 Por. H. von Campenhausen, Ojcowie Kościoła, dz. cyt., s. 69.

${ }_{34}$ Por. B. Altaner, A. Stuiber, Patrologia, dz. cyt., s. 379; F. Drączkowski, Patrologia, dz. cyt., s. 192; H. von Campenhausen, Ojcowie Kościoła, dz. cyt., s. 246. 
nakreślił ideał, „podając w formie opowieści przepisy życia pustelniczego” 35 . Razem ze św. Bazylim Wielkim ${ }^{36}$ opracowywał dwie reguły monastyczne, oparte na Piśmie Świętym ${ }^{37}$. Święty Bazyli uważany jest za prawodawcę i twórcę życia monastycznego na Wschodzie. Życie mnicha, zdaniem św. Bazylego Wielkiego, jest związane zasadniczo z życiem we wspólnocie ${ }^{38}$, chociaż organizował on także siedziby dla ascetów i pustelników ${ }^{39}$.

Natomiast w przypadku św. Augustyna Żywot św. Antoniego wywarł duży wpływ przy jego nawróceniu ${ }^{40}$. Augustyn nie myślał o tym, by zostać pustelnikiem. Naśladował św. Antoniego tylko przez całkowite zerwanie z dotychczasowym życiem ${ }^{41}$. Podobnie jak św. Antoni przyjął słowa Pisma Świętego jako osobiście skierowane do siebie i zastosował je w życiu ${ }^{42}$. Po swoim nawróceniu prowadził spokojne, pobożne życie z przyjaciółmi, poświęcone pracy umysłowej, gdzie każdy miał czas na skupienie i na prywatne studia, a dyskusje były przerywane śpiewaniem hymnów i wspólną modlitwą ${ }^{43}$. Matka św. Augustyna, św. Monika, uczestniczyła w tym życiu. Po jej śmierci św. Augustyn przybył do Tagasty i tam z gronem przyjaciół założył klasztor w swym domu rodzinnym $^{44}$. Jako biskup Hippony zachował formę życia ascetycznego. Na przekazanym mu gruncie wybudował nowy klasztor, do którego przeniosła się część przyjaciół z Tagasty oraz wstąpili nowi członkowie ${ }^{45}$. Dla nich opracował regułę, która jest pierwszą zachodnią regułą monastyczną ${ }^{46}$. Święty Augustyn wpłynął też na swoich duchownych, by przystąpili do tej wspólnoty. Praca ręczna

35 Św. Grzegorz z Nazjanzu, Mowa 21. Pochwała Wielkiego Atanazego, biskupa Aleksandrii (PG 35, k. 1081-1128), nr 5, w: Święty Grzegorz z Nazjanzu, Mowy wybrane, pr. zbior., Warszawa 1967, s. 228.

${ }^{36}$ Zob. Św. Bazyli Wielki, Pisma ascetyczne, t. 2, Reguły dłuższe. Reguły krótsze, przekł. i oprac. J. Naumowicz, Tyniec-Kraków 1995.

37 Por. F. Drączkowski, Patrologia, dz. cyt., s. 219, 229.

${ }_{38}$ Por. H. von Campenhausen, Ojcowie Kościoła, dz. cyt., s. 74.

39 Por. Wstęp, w: Św. Bazyli Wielki, Pisma ascetyczne, t. 1, przekł. i oprac. J. Naumowicz, Kraków-Tyniec 1994, s. 26.

$4^{\circ}$ Zob. Św. Augustyn, Wyznania viıI 6; 12, tłumaczył oraz wstępem i kalendarium opatrzył Z. Kubiak, Kraków 1994, s. 171, 183.

${ }^{41}$ Por. H. von Campenhausen, Ojcowie Kościoła, dz. cyt., s. 287.

${ }^{42}$ Św. Augustyn, Wyznania viri 12, dz. cyt., s. 183.

43 Por. H. von Campenhausen, Ojcowie Kościoła, dz. cyt., s. 287-288.

${ }^{44}$ Por. H. von Campenhausen, Ojcowie Kościoła, dz. cyt., s. 295.

${ }^{45}$ Por. F. Drączkowski, Patrologia, dz. cyt., s. 360; H. von Campenhausen, Ojcowie Kościoła, dz. cyt., s. 303 .

${ }^{46}$ Por. F. Drączkowski, Patrologia, dz. cyt., s. 367. 
w ich przypadku została zastąpiona przez pracę duszpasterską ${ }^{47}$. W przypadku św. Augustyna nie mamy zatem do czynienia z życiem pustelniczym, choć według jego reguły żyją dziś paulini, Zakon św. Pawła Pierwszego Pustelnika.

W Żywocie napisanym przez św. Atanazego mowa jest o tym, że św. Antoni życia pustelniczego uczył się od innych ascetów. U jednych podziwiał czuwania, u innych oddawanie się lekturom albo posty i spanie na gołej ziemi. Wzbogacony tymi przykładami, starał się być obrazem wszystkich cnót, jakie spotykał u innych ${ }^{48}$. Święty Antoni czerpał przykład również z proroka Eliasza. W Żywocie jest zapis o tym, że św. Antoni mówił sobie, że asceta powinien czerpać nauki ze sposobu życia wielkiego Eliasza i swoje życie oglądać zawsze w jego życiu jak w lustrze ${ }^{49}$.

Po okresie początkowym, podczas którego św. Antoni uczył się życia ascetycznego od innych, prawie dwadzieścia lat spędził samotnie, „sam nie wychodząc i przez nikogo nie widziany. Ale potem przyszło wielu, którzy głęboko pragnęli naśladować jego ascezę, i inni, którzy go znali, i siłą wyważyli drzwi wejściowe. Antoni wyszedł do nich, jak wtajemniczony w święte misteria w sekretnym miejscu świętym i jak człowiek niosący w sobie Boga"so. Nastąpił czas, kiedy św. Antoni udzielał nauk innym mnichom i uczył ich życia ascetycznego. W czasie prześladowania Kościoła za cesarza Maksymina św. Antoni opuścił pustelnię, aby towarzyszyć męczennikom, zachęcać ich do odwagi, pomagać wyznawcom, sam jednak zachował swoje życie, mimo iż pragnął męczeństwa ${ }^{51}$. Potem następowały okresy całkowitej samotności oraz czas odwiedzania mnichów. Gdy był w swojej pustelni, był odwiedzany przez innych, dotknięci chorobami ośmielili się do niego przybywać, przychodzili też mnisi ${ }^{52}$.

47 Por. H. von Campenhausen, Ojcowie Kościoła, dz. cyt., s. 303.

${ }_{48}$ Zob. Św. Atanazy Aleksandryjski, Żywot świętego Antoniego, nr 4, w: Św. Atanazy Aleksandryjski, Żywot świętego Antoniego, Św. Antoni Pustelnik, Pisma, dz. cyt., s. 58.

49 Zob. PG 26, k. 853-854, http://patristica.net/graeca/\#to26 (23.12.2016), tłum. za: Św. Atanazy Aleksandryjski, Żywot świętego Antoniego, nr 7, w: Św. Atanazy Aleksandryjski, Żywot świętego Antoniego, Św. Antoni Pustelnik, Pisma, dz. cyt., s. 61.

${ }^{50}$ PG 26, k. 863-864, http://patristica.net/graeca/\#to26 (23.12.2016), tłum. za: Św. Atanazy Aleksandryjski, Żywot świętego Antoniego, nr 14, w: Św. Atanazy Aleksandryjski, Żywot świętego Antoniego, Św. Antoni Pustelnik, Pisma, dz. cyt., s. 65.

${ }^{51}$ Zob. Atanazy Aleksandryjski, Żywot świętego Antoniego, nr 46, w: Św. Atanazy Aleksandryjski, Żywot świętego Antoniego, Św. Antoni Pustelnik, Pisma, dz. cyt., s. 84.

${ }^{2}$ Zob. Atanazy Aleksandryjski, Żywot świętego Antoniego, nr 49-94, w: Św. Atanazy Aleksandryjski, Żywot świętego Antoniego, Św. Antoni Pustelnik, Pisma, dz. cyt., s. 85-11o. 
Życie św. Antoniego nie polegało ani na całkowitym osamotnieniu, chociaż często przebywał w odosobnieniu, ani też na duszpasterstwie, choć nauczał przychodzących do niego mnichów życia ascetycznego. Prowadząc życie ascetyczne, szukał samotności. Był jednak otwarty na potrzeby braci. Żył według zasady, że „całą troskliwość należy poświęcić duszy, a nie ciału; jemu dać odpowiednie chwile, a duszy cały wolny czas i dla niej starać się o pożytek" 53 . Odstępstwem od tej zasady mogło być dobro duszy drugiego człowieka, co miało miejsce np. podczas prześladowania Kościoła ${ }^{54}$.

W tekście Żywota nie ma ani jednej wzmianki o czytaniu przez św. Antoniego ksiąg, również, gdy chodzi o Pismo Święte, choć przytoczono jego słowa, że Pisma wystarczają dla pouczenia ${ }^{55}$, wskazujące na to, że sam kierował się Pismem Świętym. W odniesieniu do modlitwy czytamy, że „modlił się nieustannie, gdy się dowiedział, że trzeba się modlić bez przerwy. A tak był uważny, kiedy czytano Pismo, że ani jedno słowo nie padło na ziemię, wszystko zapamiętywał tak, że w końcu pamięć zastępowała mu księgi" ${ }^{\text {"6 }}$. Przyswajanie na pamięć wersetów biblijnych czy całych psalmów, aby łatwiej było nad nimi medytować w ciągu dnia, jest stosowaną praktyką zarówno w starożytności, jak i współcześnie. Nie dziwi zatem taka praktyka u pustelnika. Jednakże na podstawie Żywota nie można wysnuć wniosku, że św. Antoni sam nie czytał świętych ksiąg, bo był niepiśmienny. Chęć gruntowniejszego poznania Pisma Świętego mogła go skłonić do opanowania umiejętności czytania i posługiwania się koptyjskimi przekładami Biblii ${ }^{57}$. Pachomiusz wręcz nakazywał uczenie mnichów, jeśli wstępując do zakonu, byli niepiśmienni ${ }^{5}$. Może to świadczyć o głęboko zakorzenionej świadomości, że Pismo Święte zawiera słowo Boga i należy je studiować.

53 PG 26, k. 909-910, http://patristica.net/graeca/\#to26 (23.12.2016), tłum. za: Św. Atanazy Aleksandryjski, Żywot świętego Antoniego, nr 45, w: Św. Atanazy Aleksandryjski, Żywot świętego Antoniego, Św. Antoni Pustelnik, Pisma, dz. cyt., s. 83.

${ }_{4}$ Zob. Św. Atanazy Aleksandryjski, Żywot świętego Antoniego, nr 46, w: Św. Atanazy Aleksandryjski, Żywot świętego Antoniego, Św. Antoni Pustelnik, Pisma, dz. cyt., s. 83-84.

${ }_{55}$ Zob. Św. Atanazy Aleksandryjski, Żywot świętego Antoniego, nr 16, w: Św. Atanazy Aleksandryjski, Żywot świętego Antoniego, Św. Antoni Pustelnik, Pisma, dz. cyt., s. 66.

${ }^{56}$ PG 26, k. 845-846, http://patristica.net/graeca/\#to26 (23.12.2016), tłum. za: Św. Atanazy Aleksandryjski, Żywot świętego Antoniego, nr 3, w: Św. Atanazy Aleksandryjski, Żywot świętego Antoniego, Św. Antoni Pustelnik, Pisma, dz. cyt., s. 58.

57 Zob. Św. Atanazy Aleksandryjski, Żywot świętego Antoniego, Św. Antoni Pustelnik, Pisma, dz. cyt., s. 35 .

${ }_{58}$ Zob. Św. Atanazy Aleksandryjski, Żywot świętego Antoniego, Św. Antoni Pustelnik, Pisma, dz. cyt., s. 35 . 
Święty Antoni w ujęciu św. Atanazego był theodidaktos - uczonym przez Boga, nie przez ludzi ${ }^{59}$. Był znany ze swej pobożności. W Żywocie czytamy następującą konkluzję: „Nawet gdyby tacy ludzie żyli w ukryciu i pragnęli, aby o nich zapomniano, Pan sam ich wszystkim pokaże niczym latarnie" ${ }^{60}$.

3.2. Żywot św. Pawła Pierwszego Pustelnika i jego oddziaływanie na innych

Ewagriusz z Pontu, przyjaciel św. Hieronima, przetłumaczył $\dot{Z} y w o t$ św. Antoniego na łacinę ${ }^{61}$. Święty Hieronim, pisząc swój Żywot św. Pawła Pierwszego Pustelnika, zrobił temu pierwszemu dziełu konkurencję. Jego św. Paweł jest o wiele starszy i doskonalszy niż św. Antoni. To św. Antoni wybiera się w drogę, aby poznać św. Pawła. Treść religijna dzieła jest skromna, ale pełna uroku. Ogranicza się do ukazania pierwszych i ostatnich dni pustelnika na pustyni ${ }^{62}$. Życie pustelnicze fascynowało św. Hieronima. Przyjaźnił się ze św. Grzegorzem z Nazjanzu, któremu te ideały również były bliskie. Święty Hieronim podjął próbę życia ascetycznego na pustyni Chalkis, gdzie w rozproszeniu żyli eremici. Zapewne św. Hieronim zajął jakąś wolną pieczarę. Musiała być przestronna, bowiem przeniósł tam całą swoją bibliotekę, przepisywał w niej książki, a z czasem przyjmował też odwiedzających. Anachoreci nie byli całkowicie odcięci ani od siebie, ani od świata zewnętrznego. Święty Hieronim regularnie otrzymywał i wysyłał swoją korespondencję. Cisza pomagała mu uporządkować myśli, z którymi pragnął się wymieniać z innymi i utrzymywać z nimi kontakt listowny. Sprowadzał do swojej pustelni książki. Pozyskał też towarzyszy, którzy je przepisywali, i dzięki temu nie tylko pomnożył swoją bibliotekę, lecz również jak prawdziwy mnich mógł zapewnić sobie utrzymanie ${ }^{63}$. Na pustyni Chalkis spędził dwa i pół roku. Jednakże jego rozwój intelektualny nie osiągnął wówczas jeszcze pełni, a pustynne miejsce nie mogło zapewnić mu tych możliwości naukowych, za którymi tęsknił. Dopiero po wielu latach, w Betlejem, udało mu się znaleźć właściwe sobie, indywidualne połączenie pracy umysłowej, ascezy i łączności z ludźmi, i temu rozwiązaniu pozostał wierny do końca życia ${ }^{64}$.

59 Zob. Św. Atanazy Aleksandryjski, Żywot świętego Antoniego, Św. Antoni Pustelnik, Pisma, dz. cyt., s. 36 .

${ }^{60}$ PG 26, k. 973-974, http://patristica.net/graeca/\#to26 (22.12.2016), tłum. za: Św. Atanazy Aleksandryjski, Żywot świętego Antoniego, nr 93, w: Św. Atanazy Aleksandryjski, Żywot świętego Antoniego, Św. Antoni Pustelnik, Pisma, dz. cyt., s. 111.

${ }_{61}$ Por. H. von Campenhausen, Ojcowie Kościoła, dz. cyt., s. 246.

${ }_{62}$ Por. H. von Campenhausen, Ojcowie Kościoła, dz. cyt., s. 247.

${ }^{63}$ Por. H. von Campenhausen, Ojcowie Kościoła, dz. cyt., s. 246-247.

${ }^{64}$ Por. H. von Campenhausen, Ojcowie Kościoła, dz. cyt., s. 248. 
Na pustyni Chalkis św. Hieronim napisał Żywot św. Pawła, w którym nakreślił ideał życia pustelniczego ${ }^{65}$. Święty Paweł żyje sam na sam z Bogiem, nie mając kontaktu ze światem zewnętrznym. Bóg troszczy się o jego potrzeby. Kruk przynosi chleb, źródło daje wodę, palma daktyle. Lwy wykopują grób. Święty Paweł pochowany w płaszczu św. Atanazego przez św. Antoniego jest dla św. Hieronima symbolem pustelnika, który prowadzi wprawdzie życie ukryte z Bogiem, ale przez swój przykład oddziałuje na innych. Święty Antoni wróciwszy do swojego klasztoru po pochowaniu pierwszego pustelnika, w uroczyste dni Paschy i Zesłania Ducha Świętego przyodziewał zawsze tunikę Pawła ${ }^{66}$, czym daje wyraz uznania św. Pawła za pierwszego i doskonalszego pustelnika.

Do dzisiaj św. Paweł Pustelnik jest czczony w Egipcie przez mnichów koptyjskich. Znamienna jest wzmianka o tym o. Joachima A. Dembickiego osPPE w relacji z pielgrzymki do groty św. Pawła z Teb: „Podobnie jak św. Antoni - opat, św. Paweł Pustelnik uważany jest i czczony jako święty, który leczy, chroni, pomaga i umacnia wierzących chrześcijan w Egipcie. Wprawdzie św. Antoni wywarł większy wpływ w historii Kościoła niż św. Paweł, to jednak Egipcjanie zdają się preferować modlitwę za wstawiennictwem św. Pawła I Pustelnika, ponieważ, jak mówią: «On jest bardziej skory do wysłuchania modlitwy biednego i odpowiedzenia szybciej niż Ojciec Antoni - a to jest przecież najważniejsze»" ${ }^{\text {" }}$.

Na pewno z Żywota św. Pawła Pierwszego Pustelnika nie można wysnuć jakiejś reguły życia pustelniczego, jak miało to miejsce w przypadku Żywota św. Antoniego. Jednakże można wypunktować pewne ważne cechy charakteryzujące pustelnika.

Przede wszystkim pustelnik jest człowiekiem uczonym przez Boga. To z Bogiem przebywa sam na sam, oddzielony od świata. Pustynia jest jego środowiskiem, które cechuje się surowością życia i ubóstwem.

Przykład św. Pawła i św. Hieronima uczy, że każdy chrześcijanin, nawet ten zafascynowany życiem pustelniczym, winien indywidualnie rozeznać swoje powołanie. Święty Paweł, udając się na pustynię z konieczności, by tam przeczekać prześladowanie, $\mathrm{z}$ czasem zamienił konieczność na dobrowolny wybór

${ }_{65}$ Por. H. von Campenhausen, Ojcowie Kościoła, dz. cyt., s. 246.

${ }^{66}$ Zob. PL 23, k. 28, http://patristica.net/latina/ (27.12.2016); Św. Hieronim, Żywot św. Pawła Pierwszego Pustelnika, dz. cyt., nr 16, s. 39.

67 J. A. Dembicki osppe, W Grocie Świętego Pawła I Pustelnika, http://www.jasnagora.com/ wydarzenie-2398 (29.12.2016). 
i pozostał na pustyni do końca długiego życia ${ }^{68}$. Święty Hieronim przerwał życie pustelnicze, bo zatęsknił do świata, ludzi i wyzwań intelektualnych. Jako człowiek dojrzały kierował klasztorem w Betlejem, w którym znajdował się dom dla pielgrzymów i szkoła. Św. Hieronim wygłaszał do mnichów kazania, a w szkole uczył wychowanków świeckich przedmiotów. W Betlejem spędził św. Hieronim trzydzieści cztery lata i pominąwszy niedalekie podróże do sąsiednich miejscowości, nie opuścił go już aż do śmierci. Tam tłumaczył księgi Pisma Świętego, a także pisał wielkie prace biblijne i rozprawy polemiczne. Poświęcał się pracy naukowej, a jednocześnie brał udział w gwałtownych sporach teologicznych ${ }^{69}$. Nie prowadził życia pustelniczego w ścisłym tego słowa znaczeniu. Nie było mowy wówczas jeszcze o obowiązku porzucenia świata ani też o konieczności milczenia ${ }^{70}$.

\section{Charakterystyka życia pustelniczego w oparciu o współczesny kodeks prawa kanonicznego}

Współczesne życie pustelnicze normowane jest przez kodeks prawa kanonicznego, który określa je jako życie charakteryzujące się surowszym odsunięciem się od świata, milczeniem odosobnienia, gorliwą modlitwą i pokutą, dzięki której pustelnik poświęca swoje życie na chwałę Boga i zbawienie świata ${ }^{71}$. Wyliczone w kanonie istotne elementy życia pustelniczego decydują o odrębności tej formy życia konsekrowanego ${ }^{72}$.

\subsection{Odsunięcie się od świata}

Pierwszą cechą charakterystyczną dla pustelnika jest życie odsunięte od świata, życie kontemplacyjne. Życie dziewic i stan wdów jest życiem konsekrowanym w świecie, które możemy określić jako czynne.

Życie kontemplacyjne, zatwierdzone przez autorytet Kościoła, co ma miejsce podczas publicznych ślubów wobec biskupa diecezjalnego, jest życiem ukrytym, w którym człowiek, porzuciwszy troskę o wszelkie rzeczy doczesne

68 Zob. PL 23, k. 20-21, http://patristica.net/latina/ (27.12.2016); Św. Hieronim, Żywot św. Pawła Pierwszego Pustelnika, dz. cyt., nr 5, s. 33.

69 Por. S. Pieszczoch, Patrologia, t. 1: Działalność Ojców, Gniezno 1994, s. 113.

70 Por. H. von Campenhausen, Ojcowie Kościoła, dz. cyt., s. 257-258.

71 Zob. KPK, kan. $603 \S 1$.

72 Por. G. Bartoszewski, Prawne podstawy dla indywidualnych form życia konsekrowanego, http://www.zyciezakonne.pl/dokumenty/referaty-konferencje-artykuly/zagadnienia-prawne/ bartoszewski-g-ofmcap-prawne-podstawy-dla-indywidualnych-form-zycia-konsekrowanego-30254/ (13.01.2017). 
i duchowe, żyje sam na sam z Bogiem. Życie czynne polega na podejmowaniu zadań apostolskich i dzieł miłosierdzia. Te działania również domagają się pogłębionej modlitwy i z niej wypływają, ale modlitwa niejako towarzyszy życiu czynnemu. W życiu kontemplacyjnym modlitwa jest główną powinnością, z której nie wynika konkretne zaangażowanie. Dlatego też pustelnik nie zajmuje się duszpasterstwem ${ }^{73}$. Jeżeli udziela jakiś porad duchowych odwiedzającym, czyni to sporadycznie i na wyraźną prośbę, sam nie wyznacza godzin odwiedzin i nie podejmuje się prowadzenia kierownictwa duchowego. Jest całkowicie zaangażowany w życie kontemplacyjne, które może prowadzić go do życia mistycznego.

Prawodawca kościelny bardzo ogólnie mówi o odsunięciu się od świata. Niektórzy uważają, że w obecnych warunkach społecznych nie musi to być odsunięcie się w dawnej tradycyjnej formie i może ono przybrać inną postać, która jednak wiąże się zawsze z rzeczywistym odsunięciem się i życiem samotnym $^{74}$.

Jan Paweł II w adhortacji apostolskiej Vita consecrata napisał, że pustelnik przez wewnętrzne i zewnętrzne oderwanie od świata świadczy o przemijalności obecnej epoki, a przez post i pokutę ukazuje, że nie samym chlebem żyje człowiek, ale słowem Bożym ${ }^{75}$. Tego rodzaju „życie na pustyni” jest wezwaniem skierowanym do całej wspólnoty kościelnej, aby nie traciła nigdy $\mathrm{z}$ oczu najwyższego powołania, które polega na nieustannym przebywaniu z Panem ${ }^{76}$. Podobnie Katechizm Kościoła Katolickiego podaje, że pustelnik ukazuje każdemu wewnętrzny aspekt tajemnicy Kościoła, którym jest osobowa bliskość z Chrystusem ${ }^{77}$. Ukryte przed światem życie pustelnika jest milczącym przepowiadaniem Chrystusa, któremu oddał swoje życie, ponieważ jest

73 Mamy wprawdzie Zakon Świętego Pawła Pierwszego Pustelnika (paulinów). Jednakże sami paulini określają siebie jako zakon kontemplacyjno-czynny, ukształtowany z biegiem lat jako zakon klerycki. Jako zasadniczy kształt swojej duchowości wymieniają dwa główne nurty życia zakonu: życie kontemplacyjne i działalność apostolską - http://www.paulini.pl/pl/14,Charyzmat-Zakonu (10.11.2016). Paulini żyją według reguły św. Augustyna. Por. J. S. Płatek, Początki Zakonu św. Pawła Pierwszego Pustelnika..., dz. cyt., s. 72-92. Zakon paulinów nie jest zatem zakonem pustelników w ścisłym tego słowa znaczeniu, w jakim rozumiani są pustelnicy w niniejszym artykule.

74 Por. G. Bartoszewski, Prawne podstawy dla indywidualnych form życia konsekrowanego, dz. cyt. (13.01.2017).

75 Jan Paweł II, Adhortacja apostolska o życiu konsekrowanym i jego misji w Kościele i w świecie Vita consecrata [dalej: vc], Częstochowa 1996, nr 7.

${ }^{76}$ Zob. ve 7.

77 Zob. Katechizm Kościoła Katolickiego [dalej: KKK], Poznań 199, nr 921. 
On dla niego wszystkim. Pustelnik przez oddalenie się od świata jest czytelnym znakiem prymatu rzeczywistości niebieskich nad doczesnymi ${ }^{78}$.

Surowsze odsunięcie się od świata poza życiem samotnym zakłada także ubóstwo, poprzestawanie na tym, co wystarcza. Dlatego też prowadzący życie kontemplacyjne powinni ogołocić się z dóbr doczesnych. Pustelnik nie może żyć w luksusie. Surowsze odsunięcie się od świata nie oznacza tylko odosobnienia, lecz również pewną surowość życia w odniesieniu do wyposażenia mieszkania, ubrania i jedzenia.

Surowsze odsunięcie się od świata niekoniecznie oznacza zamieszkanie na odludziu. Obecnie wielu pustelników ma swoje pustelnie w mieście ${ }^{79}$. Jest to chyba dobre rozwiązanie dla kobiet, które prowadzą ten styl życia. Samotne zamieszkiwanie kobiety na odludziu mogłoby ją narażać na niebezpieczeństwo. Ewa Wipszycka, historyk starożytności, badająca początki monastycyzmu w Egipcie, stwierdziła, że nie spotkała się z przykładem anachoretyzmu kobiecego, a monastycyzm kobiecy zaczął się od razu od formy klasztornej ${ }^{80}$. Oczywiście nie mówimy o zjawisku ascezy domowej, której oddawały się kobiety w swoich domach przed nastaniem czasów mniszek ${ }^{81}$ i która prowadziła do utworzenia się stanu dziewic ${ }^{82}$.

W odniesieniu do wymogu odsunięcia się od świata mówi się o potrzebie przypatrywania się praktyce życia zakonów kontemplacyjnych ${ }^{83}$. Jednakże należy zwrócić uwagę, że w przypadku pustelników mamy do czynienia z indywidualnym życiem kontemplacyjnym, w którym pustelnik musi sam troszczyć się o swoje utrzymanie, pracę, ewentualne remonty itp. Jego kontakty ze światem będą inne niż osób żyjących za tzw. klauzurą papieską, która jest zgodna $\mathrm{z}$ zasadami określonymi przez Stolicę Apostolską ${ }^{84}$. W zakonach tylko osoby do tego wyznaczone zajmują się troską o utrzymanie wspólnoty. Poza tym

78 Zob. KKк 921.

79 Por. H. Śmiarowski, Pustelnicza droga, http://www.ifzk.episkopat.pl/dokumenty/pustelnicza_ droga.pdf (12.11.2016).

${ }^{80}$ Por. Mnisi nie tylko ci święci... Z prof. Ewa Wipszycką o pierwszych mnichach na pustyni egipskiej rozmawia Szymon Hiżycki OsB, Kraków-Tyniec 2007, s. 97.

${ }^{81}$ Por. Mnisi nie tylko ci święci..., dz. cyt., s. 95.

${ }_{82}$ Por. B. Stypułkowska, Indywidualne formy życia konsekrowanego w kontekście roku życia konsekrowanego, dz. cyt., s. 125-128.

${ }^{83}$ Materiały z sympozjum zatytułowanego Duchowość pustelnicza - szanse i zagrożenia, które odbyło się 5 listopada 2016 roku w Warszawie zob. http://www.ifzk.episkopat.pl/sympozjum_2016pustelnicy.php (11.01.2017).

${ }^{84}$ Por. KPK, kan. $667 \$ 3$. 
niektóre zakony kontemplacyjne specjalizują się w modlitwie wstawienniczej, stąd rodzi się np. potrzeba prowadzenia stron internetowych ze skrzynką intencji. Pustelnik odsuwa się od świata właśnie w tym celu, by nie utrzymywać kontaktów z ludźmi, ale żyć sam na sam z Bogiem. Aby oddawać się modlitwie wstawienniczej, nie trzeba odchodzić na pustynię, przeciwnie, powinno się żyć w świecie, blisko ludzi.

\subsection{Milczenie odosobnienia}

Milczenie odosobnienia zakłada życie w ciszy, ale także ograniczenie kontaktów ze światem. Dotyczy to również ograniczenia dostępu do informacji. Pustelnikowi nie jest potrzebna znajomość intencji modlitewnych, ponieważ on nie zajmuje się modlitwą wstawienniczą. Pustelnik żyje przede wszystkim Bogiem. Bóg jest godzien tego, aby niektórzy chrześcijanie poświęcili swoje życie, aby Go szukać, aby żyć w Jego obecności w nieustannym hołdzie uwielbienia, dziękczynienia i błagania. Prosząc o przebaczenie i łaskę, pustelnik myśli najpierw o sobie, ale mówiąc o sobie, wyznaje nędzę całej ludzkości i dzięki temu cała ludzkość odnosi korzyść z jego pokory i łaski, jaką otrzymuje ${ }^{85}$.

Milczenie odosobnienia zakłada to, że pustelnik nie będzie dzielił się z innymi swoim doświadczeniem Boga. Jego modlitwa pozostanie ukryta. Jednakże efekty jego medytacji i studium mogłyby być zapisywane. Wydaje się, że pustelnik mógłby uprawiać teologię, zwłaszcza teologię monastyczną, gdzie studium związane jest ściśle z modlitwą. Zapisywanie poruszeń serca przy czytaniu słowa Bożego, wniosków wysnuwanych z lektury może być pożyteczne dla samego pustelnika, gdyż może on wrócić do dawniejszych poruszeń, przywołać treści wcześniej odkryte. Zapiski te jednak winny być sporządzane z myślą o osobistym użytku, a nie w celach duszpasterskich czy ewangelizacyjnych, bo to nie należy do charakteru życia pustelniczego. Po śmierci danego pustelnika warto takie zapiski umieścić $\mathrm{w}$ archiwum diecezjalnym lub ewentualnie rozważyć celowość ich publikacji.

Jan Paweł II w liście apostolskim Orientale lumen zwrócił uwagę na to, że różne formy monastycyzmu od życia we wspólnocie, jakie praktykowali św. Pachomiusz czy św. Bazyli Wielki, do życia w samotności, jakie praktykowali św. Antoni czy św. Makary Egipski, odpowiadają raczej różnym etapom drogi duchowej, a nie różnym wyborom stanu życia ${ }^{86}$. Oznacza to, że również

${ }^{85}$ Por. J. Leclercq, Sam na sam z Bogiem. Życie pustelnicze na podstawie doktryny błogosławionego Pawła Giustinianiego, przekł. E. Buszewicz, Kraków-Tyniec 2014, s. 71-72.

${ }^{86}$ Zob. Jan Paweł II, List apostolski Orientale lumen w setną rocznicę listu apostolskiego Orientalium dignitas papieża Leona XıII, $\mathrm{nr}$ 9, https://opoka.org.pl/biblioteka/W/WP/jan_pawel_II/ 
współczesny pustelnik może przechodzić przez różne etapy odosobnienia. Oderwanie od świata niekoniecznie oznacza całkowite odosobnienie od ludzi. Milczenie odosobnienia nie zawsze oznacza życie w całkowitej samotności. Wycofanie się pustelnika na pustynię w celu osiągnięcia świętości oddziaływało na innych chrześcijan. W historii początków pustelnictwa spotykamy się niejednokrotnie z sytuacją, że do pustelnika dołączali inni adepci, pragnący prowadzić taki sam tryb życia. Zdarzało się, że niektórzy pustelnicy byli gromadnie odwiedzani. Ludzie przybywali do pustelnika prosić o wstawiennictwo w modlitwie, uzdrowienie z chorób duszy i ciała, poradę. Jedni wracali zbudowani i pocieszeni, inni, pociągnięci przykładem, osiedlali się w pobliżu i poddając się jego kierownictwu, sami z kolei próbowali naśladować jego sposób życia ${ }^{87}$. Już św. Antoni jest przykładem na to, że samotność na pustyni nie jest niezbędnym warunkiem drogi pustelniczej. Po pewnym czasie św. Antoni zrezygnował z izolacji i zaakceptował obecność uczniów, którzy prosili go o to, by stał się ich mistrzem $^{88}$. To właśnie dlatego powstają pierwsze reguły dla anachoretów, które kładą nacisk na wspólne życie i władzę przełożonego nad ogółem klasztorów, ograniczają indywidualne inicjatywy wybujałego ascetyzmu, organizują warsztaty klasztorne, pracę ręczną, czytanie Biblii i kładą nacisk na posłuszeństwo ${ }^{89}$.

Obecnie, w polskich materiałach znajdujących się na stronie internetowej Podkomisji Konferencji Episkopatu Polski [dalej: KEP] ds. Indywidualnych Form Życia Konsekrowanego [dalej: IFŻK], dopuszcza się możliwość udzielania pomocy duchowej przez pustelnika osobom przybywającym po rady duchowe. Jest nawet zalecenie, aby pustelnik określił to w swojej regule życia, czyli statucie osobowym pustelnika ${ }^{90}$. Jednakże należy pamiętać, że samotność i oddzielenie się od ludzi w celu prowadzenia życia kontemplacyjnego jest

listy/orientale_lumen_02051995.html (29.11.2018).

${ }^{87}$ Por. J. Daniélou, H. I. Marrou, Historia Kościoła, dz. cyt., s. 212; T. Manteuffel, Historia powszechna. Średniowiecze, Warszawa 1968, s. 28-29.

${ }^{88}$ Zob. Św. Atanazy Aleksandryjski, Żywot świętego Antoniego, nr 14, w: Św. Atanazy Aleksandryjski, Żywot świętego Antoniego, Św. Antoni Pustelnik, Pisma, dz. cyt., s. 65; E. Wipszycka, R. Wiśniewski, Wstęp, w: Historia mnichów w Egipcie, dz. cyt., s. 8.

${ }^{89}$ Por. M. Simon, Cywilizacja wczesnego chrześcijaństwa I-IV w., przeł. E. Bękowska, Warszawa 1992, s. 364.

${ }^{90}$ Por. H. Śmiarowski, Niektóre wskazania duszpasterskie..., dz. cyt. Autor w przypisie podaje odwołanie do Resource Material for the Discernment of Hermit Vocations according to canon 603. From the Congregation of Institutes on Religious Life and Societies of Apostolic Life, ale w oryginalnym tekście nie ma mowy o zaangażowaniu pustelnika w świadczenie pomocy duchowej. Zob. http:// www.quies.org/DiscerningEremiticalLifefromCongcL.pdf (13.01.2017). 
istotnym rysem życia pustelniczego. Przewidywanie działalności o jakimkolwiek charakterze duszpasterskim i wynikających stąd kontaktów nie należy do duchowości pustelniczej. Wszelkie zaangażowanie winno być głęboko przemyślane. Jest ono natomiast uzasadnione np. w sytuacji, gdy pustelnikiem zostaje prezbiter mający swoich stałych penitentów, wobec których prowadzi kierownictwo duchowe. W przypadku świeckiego pustelnika mogą również zdarzyć się sytuacje, że ktoś będzie chciał uzyskać poradę duchową i będzie przyjeżdżał regularnie w odwiedziny. Jednakże wyznaczanie ze strony pustelnika odgórnie terminów takich spotkań i ogłaszanie ich do publicznej wiadomości wydaje się niezgodne $\mathrm{z}$ jego powołaniem.

\subsection{Gorliwa modlitwa}

Modlitwa powinna być znakiem każdego chrześcijanina. Gorliwa modlitwa charakteryzuje osoby życia konsekrowanego. Jest zatem wyróżnikiem również dla pustelników.

Kodeks prawa kanonicznego w kanonach 663-664 wymienia obowiązki członków instytutów życia konsekrowanego odnoszące się do modlitwy i życia sakramentalnego. Można przyjąć, że są to obowiązki wszystkich osób konsekrowanych, w tym pustelników.

W kanonie $663 \$ 1$ KPK mowa jest o tym, że pierwszym i podstawowym obowiązkiem osób życia konsekrowanego powinna być kontemplacja rzeczy Bożych oraz ustawiczne zjednoczenie z Bogiem w modlitwie.

Kanon $663 \$ 2$ KPK podaje, że członkowie instytutów powinni wedle możności codziennie uczestniczyć we mszy świętej, przyjmować Komunię świętą i adorować Najświętszy Sakrament. Ważne wydaje się tutaj stwierdzenie „wedle możności", które dopuszcza pewne odstępstwa od tej zasady.

W kanonie $663 \$ 3$ KPK wymieniony został obowiązek czytania Pisma Świętego i odprawiania rozmyślania według przepisów własnego prawa, sprawowania liturgii godzin oraz praktykowania innych pobożnych ćwiczeń. Każdy instytut, a w przypadku indywidualnych form życia konsekrowanego - każdy konsekrowany, winien sprecyzować czas i sposób lectio divina. Niekoniecznie chodzi tutaj o praktykowanie metody lectio divina według trzech etapów: lectio, meditatio i oratio, choć dla pustelników mogą być one bardzo przydatne.

Kanon $663 \$ 4 \mathrm{KPK}$ poświęcony jest Maryi. Osoby konsekrowane mają mieć do Niej specjalne nabożeństwo, również przez modlitwę różańcową, ponieważ 
jest Ona wzorem i oparciem dla każdego rodzaju życia konsekrowanego. Najświętsza Maryja Panna jest wzywana jako Królowa pustelników ${ }^{91}$.

W kanonie $663 \$ 5$ KPK mowa jest o praktykowaniu okresów corocznego świętego skupienia. W odniesieniu do pustelników paragraf ten nie ma zastosowania, ponieważ żyją oni w ciągłym skupieniu.

Kanon 664 przypomina o tym, że zakonnicy mają często zwracać swoją myśl ku Bogu, codziennie czynić rachunek sumienia i często przystępować do sakramentu pokuty.

\subsection{Pokuta}

Pokuta rozpatrywana jako cnota oznacza stałe wewnętrzne nastawienie, które wyraża moralną i religijną postawę człowieka wobec grzechu. Jest ona nadprzyrodzoną sprawnością moralną skłaniającą człowieka do odczuwania bólu duchowego z powodu popełnionego zła i obrazy Boga. Istotę pokuty stanowi nawrócenie. Do jej praktykowania jest wezwana cała wspólnota kościelna. Cnota pokuty pomaga zachować należytą postawę wobec rzeczywistości ziemskich oraz chroni przed przesadnym konsumpcjonizmem i żądzą użycia, w sensie duchowym ma wartość leczniczo-wychowawczą. Dlatego pokuta powinna nie tylko leżeć u podstaw formacji duchowej, lecz winna być programem i streszczeniem całego życia chrześcijańskiego ${ }^{92}$.

Do tradycyjnych dzieł pokutnych należą: post, modlitwa i jałmużna, w których streszcza się ascetyczny styl życia. Był on zalecany przez Kościół publicznym pokutnikom w okresie ekspiacji ${ }^{93}$, ale może być prowadzony przez każdego chrześcijanina. Od pierwszych wieków chrześcijaństwa w takim stylu życia przewodnią rolę odgrywają mnisi i mniszki. Charakteryzuje on również pustelników. Wśród praktyk ascetycznych pustelników wyróżnia się: drogę zjednoczenia z Bogiem przez modlitwę, medytację słowa Bożego, wyrzeczenie się pokarmów i wygód życia oraz milczenie ${ }^{94}$. Pustelnicy praktykują post. Jest on według słów Jezusa znakiem oczekiwania na przyjście Oblubieńca. Na pytanie uczniów Jana, dlaczego uczniowie Jezusa nie poszczą, Jezus od-

${ }^{91}$ W zakonie paulinów Najświętsza Maryja Panna Królowa pustelników i Matka zakonu czczona jest oddzielnym świętem 16 stycznia, nazajutrz po uroczystości św. Pawła Pierwszego Pustelnika. Zob. Kalendarz liturgiczny archidiecezji częstochowskiej na rok 2017, oprac. K. Bełkot, Częstochowa 2016, s. 112. Święto to ma własną ewangelię, kolektę i prefację. Zob. http://brewiarz. pl/i_17/1601w4/czyt.php3 (16.01.2017).

${ }^{22}$ Por. M. Chmielewski, Pokuta, w: Leksykon duchowości katolickiej, red. M. Chmielewski, Lublin-Kraków 2002, s. 649.

93 Por. J. Daniélou, H. I. Marrou, Historia Kościoła, dz. cyt., s. 238.

${ }^{94}$ Por. T. Kaczmarek, Ideały życia pustelniczego w IV wieku, dz. cyt., s. 65-69. 
powiedział: „Czy goście weselni mogą się smucić, dopóki pan młody jest z nimi? Lecz przyjdzie czas, kiedy zabiorą im pana młodego, a wtedy będą pościć” (Mt 9, 15).

\section{Tradycyjne zajęcia pustelnika}

W starożytnej regule przypisywanej św. Antoniemu tak określono zajęcia pustelnika: „Gdy będziesz przebywał w swojej celi, oddawaj się tym trzem zajęciom: pracy ręcznej, czytaniu psalmów i modlitwie”95.

Pustelnikami byli zarówno ludzie wykształceni, również teologowie i filozofowie, jak i analfabeci. Tych ostatnich nakłaniano do opanowania umiejętności czytania i pisania. Jeśli przerastało to ich umiejętności, winni byli nauczyć się na pamięć tekstów modlitw i psalmów, aby brać czynny udział w liturgii ${ }^{96}$.

W regule bł. Pawła Giustinianiego napisanej w roku $1516^{97}$ podobnie ujęto tradycyjne zajęcia pustelników: „Każdy będzie się starał zajmować pracą fizyczną w określonych, odpowiednich i wydzielonych na to godzinach, podczas gdy pozostałe godziny przeznaczone są na czytanie, modlitwę i inne zajęcia duchowe, tak, aby cały dzień i cała noc wydawały się krótkie i niewystarczające, i aby pozostawało zawsze więcej rzeczy do zrobienia niż czasu na nie" ${ }^{98}$. Na temat psalmodii liturgicznej i prywatnego odmawiania psalmów mowa jest w innych częściach reguły ${ }^{99}$. Ćwiczenia duchowe bł. Paweł Giustiniani dzieli na trzy kategorie: „Cały czas, którego pustelnicy nie mogą wykorzystać na pracę fizyczną, jest przeznaczony na studiowanie, psalmodię i modlitwy”"

Zatem wśród tradycyjnych zajęć pustelnika należałoby wymienić pracę ręczną, studium (najlepiej Pisma Świętego), psalmodię i modlitwę.

\subsection{Praca ręczna}

${ }^{95}$ PG 40, k. 1071, http://patristica.net/graeca/\#to4o (12.11.2016), tłum. za: Św. Atanazy Aleksandryjski, Żywot świętego Antoniego, Św. Antoni Pustelnik, Pisma, dz. cyt., s. 190-191.

${ }^{96}$ Por. E. Wipszycka, R. Wiśniewski, Wstęp, w: Historia mnichów w Egipcie, dz. cyt., s. 11.

${ }_{97}$ Por. J. Leclercq, Humanista-eremita. Błogosławiony Paweł Giustiniani (1476-1528), przekł.

E. Buszewicz, Kraków-Tyniec 2014, s. 241.

${ }^{98}$ Paweł Giustiniani, Regula vitae eremiticae (Reguła życia pustelniczego), Camaldoli 1520, k. 102, cyt. za: J. Leclercq, Sam na sam z Bogiem, dz. cyt., s. 99.

${ }^{99}$ Por. J. Leclercq, Sam na sam z Bogiem, dz. cyt., s. 127-134.

${ }^{100}$ Paweł Giustiniani, Regula vitae eremiticae (Reguła życia pustelniczego), Camaldoli 1520, k. 84, cyt. za: J. Leclercq, Sam na sam z Bogiem, dz. cyt., s. 117. 
Obowiązek pracy jest bardzo mocno podkreślany w apoftegmatach ${ }^{101}$. Każdy pustelnik miał obowiązek utrzymywania się z pracy rąk własnych. Praca miała służyć jego doskonaleniu się, zapewnić mu utrzymanie oraz umożliwić dawanie jałmużny. Przy minimalnych potrzebach pustelników zarobki ich były bardzo duże, co pozwalało im na hojne jałmużny i przyczyniało się do przekonania o ich bogactwie. Ojcowie pustyni nieustannie nawoływali pustelników do ubóstwa ${ }^{102}$.

Należy zwrócić uwagę na to, że w starożytności chrześcijańskiej to mnisi dawali jałmużnę, a nie prosili o nią ${ }^{103}$. Zakony żebracze pojawiły się dopiero w średniowieczu. Święty Augustyn szydzi z mnichów, którzy nie utrzymują się z własnej pracy ${ }^{104}$. Podobnie mniszki żyły z pracy własnych rąk, rozdając nadwyżki ubogim ${ }^{105}$.

W przypadku pustelników zazwyczaj mówi się o pracy ręcznej i ona jest wskazana. Taka praca sprzyja medytacji. Podczas niej można w myśli lub półgłosem recytować psalmy lub powtarzać wybrane wersety, które w danym dniu są dla nas słowem życia.

Współcześni pustelnicy mają gospodarstwa rolne, piekarnie, stolarnie. Wyrabiają kosmetyki, świece, kartki okolicznościowe ${ }^{106}$. Gdy chodzi o pracę umysłową, możliwe byłoby dla pustelnika tłumaczenie tekstów z obcych języków czy nawet przy dzisiejszych możliwościach technicznych stała praca w wydawnictwie katolickim. Praca w wydawnictwie może być podjęta poza siedzibą

${ }^{101}$ Zob. Apoftegmaty Ojców pustyni, t. 2, Kolekcja systematyczna, przekł. M. Kozera, KrakówTyniec 1995, s. 319, Księga I, 22; VI, 11. 17-18. 21; VII, 1. 27. 40; VIII, 9; X, 11. 24. 27. 46. 65. 69. 85. 107. 113; XI, 13. 17. 50; XII, 9; XIII, 13; XIV, 1. 14; XV, 87; XVI, 19; XVII, 20; XXIII, 3; Pierwsza Księga Starców. Gerontikon, dz. cyt.: Święty Antoni Wielki, nr 1 (1); Abba Arseniusz, nr 24 (62); Abba Achilles, nr 5 (128); Abba Apollos, nr 1 (149); Abba Izajasz, nr 5 (252); Abba Jan Karzeł (Kolobos), nr 2 (317), 19 (334); Abba Jan Cenobita, nr (356); Abba Lucjusz, nr (446); Abba Pistamon, nr (781); Abba Sylwan, $\mathrm{nr} 5$ (860).

${ }^{102}$ Por. M. Starowieyski, Wstęp, w: Pierwsza Księga Starców. Gerontikon, dz. cyt., s. 16.

${ }^{103}$ Por. A. G. Hamman, Życie codziennie w Afryce Pótnocnej w czasach św. Augustyna, przekł. M. Stafiej-Wróblewska, E. Sieradzińska, Warszawa 1989, s. 224-225; A. Hamman, Vie liturgique et vie sociale, Paris 1968, s. 292-293.

${ }^{104}$ Zob. S. Aurelii Augustini, De opere monachorum, nr 27, 31, in: Sancti Aurelii Augustini Hipponensis episcopi Opera omnia, tomus sextus, accurante J.-P. Migne, Parisiis 1841, PL 40, col. 569, $578 \mathrm{http}: / /$ patristica.net/latina/\#to4o (22.11.2016).

${ }^{105}$ Por. A. G. Hamman, Życie codziennie w Afryce Północnej w czasach św. Augustyna, dz. cyt., s. 226.

${ }^{106}$ Por. Bruna od Maryi, Eremityzm. Wprowadzenie w duchowość i praktykę życia pustelniczego, Warszawa-Częstochowa 2016, s. 91. 
wydawnictwa, „na odległość. Pustelnik mógłby przygotowywać publikacje, na przykład dokonywać korekty czy przygotowywać klisze do drukarni, czy nawet zajmować się drukiem książek o niewielkich nakładach. Nie mógłby natomiast być redaktorem wydania czy zajmować funkcji kierowniczych, bo do tego potrzebne jest nawiązywanie kontaktów z innymi osobami.

Praca umysłowa jednak nie sprzyja życiu pustelniczemu, oddanemu całkowicie modlitwie. Angażuje ona umysł, potrzebny jest od niej odpoczynek, który będzie jej przeciwieństwem. Odpoczynkiem dla pracy umysłowej jest zaangażowanie fizyczne. Z kolei, gdy pustelnik podejmuje pracę fizyczną, wówczas jej przeciwieństwem jest studium, medytacja i modlitwa, a więc to, co należy do głównych zajęć pustelnika.

\subsection{Studium}

Studium prowadzone przez pustelnika przede wszystkim powinno dotyczyć Pisma Świętego. Niewykluczone, że do niego może się ograniczyć. Dewiza św. Antoniego, że „same Pisma święte wystarczą nam do nauki” ${ }^{107}$, wskazuje na to, że Pismo Święte może być jedyną lekturą pustelnika. Bogactwo poszczególnych ksiąg biblijnych jest tak wielkie, że nie wystarczy całego życia, by je zgłębić. Życie w milczeniu sprzyja rozważaniu i medytacji nad słowem Bożym, które winny być poprzedzone przez studium. Nie chodzi o to, by wiele czytać, ale by czytać dogłębnie. Słowo Boże stanowi niezgłębione bogactwo, a jego poznawanie doprowadza do poznania Chrystusa, co jest celem wszystkich chrześcijan. Pustelnik w większym wymiarze niż inni może się temu oddać.

W formacji początkowej kandydatów na pustelników należy szczególną troskę położyć na wdrażanie do studium biblijnego przez wprowadzenie w charakter poszczególnych ksiąg biblijnych, podanie zasad interpretacyjnych tekstów biblijnych i przygotowanie do stosowania różnych metod biblijnych przydatnych w samodzielnym studium.

\subsection{Psalmodia}

Cechą życia mnichów jest pragnienie słowa Bożego jako jedynej lektury, w tym szczególne miejsce przyznaje się Księdze Psalmów, która jest niejako streszczeniem całego Pisma Świętego. Naukę tę wykłada św. Atanazy w Liście do Marcelina o interpretacji psalmó w ${ }^{108}$, który jest najstarszą w Kościele introdukcją

${ }^{107}$ Św. Atanazy Aleksandryjski, Żywot świętego Antoniego, nr 16, PG 26, k. 867, http://patristica. net/graeca/\#to26 (16.01.2017); tłum. za: A. Tronina, Wstęp, w: Św. Atanazy, List do Marcelina o interpretacji psalmów, przekł. A. Tronina, „Vox Patrum” 10 (1990) t. 18, s. 305.

${ }^{108}$ Św. Atanazy, List do Marcelina o interpretacji psalmów, dz. cyt., nr 2-9, s. 310-315. 
do Księgi Psalmów ${ }^{109}$, rozprawą na temat charakteru mesjańskiego i użytku psalmów w medytacji osobistej we wszystkich sytuacjach i potrzebach życiowych $^{110}$. Święty Atanazy zwraca uwagę na to, że gdy chodzi o inne księgi Pisma Świętego, czytający odnoszą słowa świętych autorów do tych spraw, które tam opisano, natomiast przy lekturze psalmów, obok proroctw o Zbawicielu, czytelnik przyjmuje te słowa za własne. Rozumie je i wypowiada nie jako cudze słowa, tyczące kogoś innego, ale swoje własne. Słowa psalmów stają się jego osobistą modlitwą ${ }^{111}$.

Święty Atanazy w swoim traktacie podaje wskazówki ułatwiające korzystanie z Psałterza. Ukazuje rodzaje modlitwy psalmów oraz określone sytuacje życiowe, w jakich można stosować poszczególne psalmy ${ }^{112}$. Takie zastosowanie psalmów przydatne jest w życiu każdego chrześcijanina, również pustelników.

\subsection{Modlitwa}

W modlitwie chrześcijanina można wyróżnić modlitwę liturgiczną (w odróżnieniu od modlitwy nieliturgicznej lub paraliturgicznej) oraz modlitwę prywatną (w odróżnieniu od modlitwy publicznej). Modlitwa liturgiczna zakłada udział w liturgii Kościoła. Ma ona miejsce podczas Eucharystii, przyjmowania sakramentów czy odmawiania liturgii godzin. Zwykle chodzi wówczas o modlitwę publiczną, wspólnotową, z wyjątkiem liturgii godzin, która może być odmawiana w samotności. Modlitwa prywatna dotyczy kultu pozaliturgicznego. W przeciwieństwie do modlitwy publicznej jest modlitwą indywidualną.

\subsubsection{Modlitwa liturgiczna}

Modlitwa pustelnika jest przede wszystkim modlitwą prywatną. Przy omawianiu duchowości monastycznej była zwrócona uwaga na modlitwę, którą mnich praktykuje w dwóch formach: modlitwie liturgicznej oraz modlitwie prywatnej $^{113}$. W przypadku pustelnika prymat wiedzie modlitwa prywatna. Codziennie może włączać się w modlitwę liturgiczną Kościoła jedynie przez odmawianie liturgii godzin. Będzie to zazwyczaj modlitwa indywidualna,

${ }^{109}$ Por. A. Tronina, Wstęp, Św. Atanazy, List do Marcelina o interpretacji psalmów, dz. cyt., s. 303.

${ }^{110}$ Por. S. Pieszczoch, Patrologia, dz. cyt., s. 81.

${ }^{111}$ Zob. Św. Atanazy, List do Marcelina o interpretacji psalmów, dz. cyt., nr 11, s. 316-317.

${ }^{112}$ Zob. Św. Atanazy, List do Marcelina o interpretacji psalmów, dz. cyt., nr 14-26, s. 318-326.

${ }^{113}$ Por. B. Stypułkowska, Perspektywy dla dziewic konsekrowanych, dz. cyt., s. 201; P. Galiński, Kim powinien być mnich? Powrót do źródeł... O duchowości monastycznej [cz. 3], http://ps-po.


(4.11.2016). 
chyba że będziemy mieć do czynienia w ławrą, czyli zespołem pustelni anachoretów. W odniesieniu do liturgii zaleca się ograniczenie liczby dni poświęconych różnym świętym, aby nie powtarzać ciągle tych samych psalmów. Sugeruje się przeczytanie całego Pisma Świętego w ciągu roku i odmówienie całego Psałterza w ciągu tygodnia ${ }^{114}$. Mowa jest o czasach, gdy Psałterz odmawiano w ciągu tygodnia. W obecnej liturgii godzin Psałterz rozłożony jest na cztery tygodnie. Pustelnikom warto zalecić monastyczną liturgię godzin, w której Psałterz występuje w układzie dwutygodniowym ${ }^{115}$. Trochę dziwi zapis wskazań duszpasterskich dotyczących konsekrowanych pustelników i pustelnic, zamieszczony na stronie Podkomisji KEP ds. IFŻ ${ }^{116}$, który w odniesieniu do liturgii godzin przypomina o obowiązku odmawiania brewiarza dla duchownych $z$ mocy samego prawa ${ }^{117}$, a pozostałym konsekrowanym jedynie zaleca odmawianie liturgii godzin, zwłaszcza jutrzni i nieszporów ${ }^{118}$. Zalecenie odmawiania zwłaszcza jutrzni i nieszporów występuje w odniesieniu do dziewic i wdów. Dziewice i wdowy prowadzą życie czynne i z tego powodu mogą nie mieć warunków do odmawiania pozostałych godzin liturgicznych. Pustelnik zaś, podobnie jak mnich, jest zobowiązany do modlitwy w większym stopniu niż inne osoby konsekrowane czy chrześcijanie $\mathrm{z}$ tego względu, że nie ma on innego istotnego zadania ${ }^{119}$. Liturgia godzin powinna wyznaczać jego rytm dnia.

We wskazaniach duszpasterskich podano, że podstawę życia duchowego eremity powinno stanowić Pismo Święte i codzienna Eucharystia. Ponadto usilnie zaleca się adorację Najświętszego Sakramentu ${ }^{120}$. Co do Pisma Świętego, to nie ma tu żadnych wątpliwości. Natomiast, gdy chodzi o codzienną Eucharystię i adorację Najświętszego Sakramentu, nasuwają się pytania, które dotyczą osób świeckich. Prezbiter bowiem może, a nawet powinien, codziennie odprawić mszę świętą w swojej pustelni, ma też możliwość adoracji Najświętszego Sakramentu. Gdy chodzi o osobę świecką, która mieszka

${ }^{114}$ Zob. Paweł Giustiniani, Regula vitae eremiticae (Reguła życia pustelniczego), Camaldoli 1520, k. 70-71, cyt. za: J. Leclercq, Sam na sam z Bogiem, dz. cyt., s. 128-129.

${ }^{115}$ Zob. Monastyczna liturgia godzin wydana przez Zakony Benedyktyńskie w Polsce dostępna jest w Wydawnictwie Benedyktynów w Tyńcu.

${ }^{116}$ Zob. http://www.ifzk.episkopat.pl/pustelnik.php (10.11.2016).

${ }_{117}$ Zob. KPK 1983, kan. $276 \$ 2$ n.

${ }^{118}$ Por. H. Śmiarowski, Niektóre wskazania duszpasterskie..., dz. cyt.

${ }^{119}$ Por. J. Leclercq, U źródeł duchowości Zachodu. Etapy rozwoju i elementy stałe, przekł. S. Sztuka, Kraków-Tyniec 2009, s. 350.

${ }^{120}$ Por. H. Śmiarowski, Niektóre wskazania duszpasterskie..., dz. cyt. 
w miejscu odosobnionym, oddalonym od kościoła, rodzi się pytanie, czy należy nakazywać jej codzienne wędrowanie na Eucharystię i ewentualną adorację? Poza tym, wychodząc do kościoła, powraca codziennie do świata, od którego w pustelni chce się odsunąć. W regule przypisywanej św. Antoniemu zamieszczona jest następująca wskazówka: „Nie chodź do kościoła, do którego chodzą tłumy ludzi”"121. Analogicznie można radzić, aby pustelnik unikał stykania się $\mathrm{z}$ tłumami na ulicach.

Duchowość eucharystyczna nie jest specyfiką życia pustelniczego. Życie eucharystyczne nie było wśród mnichów zbyt rozwinięte ${ }^{122}$. Również współcześnie zdarzają się pustelnicy, którzy dopuszczają lub wprost deklarują uczestnictwo we mszy świętej jedynie w niedzielę ${ }^{123}$. Zdarzają się oczywiście przypadki, że pustelnik chce codziennie uczestniczyć we mszy świętej, nawet gdy jest to związane z przemierzeniem znacznej odległości. Przykładem może być s. Hioba Kamińska z diecezji siedleckiej, która do kościoła parafialnego ze swojej pustelni ma cztery kilometry ${ }^{124}$.

O egipskich mnichach z Nutrii czytamy następujące świadectwo: „Zamieszkują miejsce pustynne, a eremy ich są w pewnej odległości od siebie [...]. Każdy przebywa sam w wielkiej ciszy. Jedynie w soboty i niedziele zbierają się w kościele i spotykają [...] widzą się tylko podczas Eucharystii”"125. Oczywiście Eucharystia w soboty i niedziele nie jest bezwzględną regułą. W odniesieniu do mnichów w Egipcie mamy jeszcze inne świadectwo: „Zalecał także Apoloniusz, żeby (o ile to możliwe) mnisi codziennie przystępowali do Tajemnic Chrystusa [...], ponieważ sam Zbawiciel tak powiedział: «Kto spożywa Ciało moje i pije Krew moją, trwa we Mnie, a Ja w nim» $(J$ 6, 56). A i samo wspominanie męki Pańskiej przynosi mnichom najwyższy pożytek"126. We współczesnych warunkach należałoby roztropnie rozważyć konieczność codziennego opuszczania swojej pustelni przez pustelnika.

${ }^{121}$ PG 40, k. 1069, http://patristica.net/graeca/\#to4o (17.11.2016), tłum. za: Św. Atanazy Aleksandryjski, Żywot świętego Antoniego, Św. Antoni Pustelnik, Pisma, dz. cyt., s. 189.

${ }^{122}$ Por. M. Starowieyski, Wstęp, w: Pierwsza Księga Starców. Gerontikon, dz. cyt., s. 19.

${ }^{123}$ Por. Bruna od Maryi, Eremityzm, dz. cyt., s. 57-58.

${ }^{124}$ Por. Powołana do pustelni. Z s. Hiobą Kamińską rozmawia Małgorzata Kołodziejczyk, http:// www.mojepowolanie.pl/3231,a,powolana-do-pustelni.htm (3.01.2017).

${ }^{125}$ Historia mnichów w Egipcie. Wersja grecka, xx, p. 7, w: Historia mnichów w Egipcie, dz. cyt., s. 13o. Podobnie o sobotniej i niedzielnej Eucharystii mowa jest w: Apoftegmaty Ojców pustyni, dz. cyt., Księga XVIII, 17, dz. cyt., s. 319.

${ }^{126}$ Historia mnichów w Egipcie. Wersja łacińska Rufina z Akwilei, Xv, p. 4-5, w: Historia mnichów $w$ Egipcie, dz. cyt., s. 201. 
W historii mamy przykład pustelnika o. Karola de Foucauld (1858-1916), którego cechowała duchowość eucharystyczna. Jednakże należy pamiętać, że Karol de Foucauld nie był pustelnikiem w naszym rozumieniu. Pragnął on bowiem żyć pośrodku świata, nie unikał okolicznych mieszkańców, przeciwnie, starał się nawiązywać znajomości, być bratem dla wszystkich ${ }^{127}$. W odniesieniu do wspólnot żyjących jego duchowością o. Karol de Foucauld pragnął, by były ośrodkami kultu eucharystycznego, by wierni mogli lepiej poznać i ukochać Chrystusa ${ }^{128}$. Należy pamiętać, że o. Karol de Foucauld był kapłanem $^{129}$, co ułatwiało mu na pustelni życie eucharystyczne.

Innym pustelnikiem o duchowości eucharystycznej był św. Charbel Makhlouf (1828-1898), libański mnich i kapłan. Codziennie w swojej pustelni odprawiał mszę świętą, spędzając cały ranek na przygotowaniu się do niej, a po jej odprawieniu przez kilka godzin trwał w dziękczynieniu. Wiele czasu, o różnych porach dnia i nocy, poświęcał na adorację Najświętszego Sakramentu oraz na odmawianie różańca przed obrazem Matki Bożej ${ }^{130}$. W tym przypadku mamy również do czynienia $\mathrm{z}$ kapłanem.

\subsubsection{Modlitwa bez metody}

Studium i psalmodia są już autentycznymi formami modlitwy, jednakże w życiu pustelniczym zalecana jest jeszcze modlitwa bez metody, która stale powinna towarzyszyć pustelnikowi. Błogosławiony Paweł Giustiniani zaleca w swojej regule: „Każdy wybierze czas, który uzna za najodpowiedniejszy i przez przynajmniej pół godziny, w jednym lub kilku odcinkach czasu, będzie trwał nieporuszenie na modlitwie"131.

Modlitwa taka ściśle jest związana ze studium i medytacją. Modlitwa pobudza do czytania i do rozmyślania, które z kolei prowadzą do modlitwy. Paweł Giustiniani pisze, że wszystkie te trzy czynności wynikają z siebie wzajemnie i wzajemnie się wspomagają. Pustelnik codziennie winien oddawać się czytaniu, rozmyślaniu i modlitwie ${ }^{132}$.

Piotr Rostworowski, opisując modlitwę określaną jako „trwanie przed Bogiem”, zauważa, że pod tą nazwą można rozumieć modlitwę człowieka bardzo

${ }^{127}$ Por. R. Voillaume, Echa Nazaretu, Kraków 1991, s. 16-18.

${ }^{128}$ Por. R. Voillaume, Echa Nazaretu, dz. cyt., s. 28.

${ }^{129}$ Por. http://brewiarz.pl/czytelnia/swieci/12-o2c.php3 (29.12.2016).

${ }^{130}$ Por. Św. Charbel Makhlouf - libański mnich, cudotwórca i uzdrowiciel, http://www.swcharbel. webs.com/ (29.12.2016).

${ }^{131}$ Paweł Giustiniani, Regula vitae eremiticae (Reguła życia pustelniczego), Camaldoli 1520, k. 83, cyt. za: J. Leclercq, Sam na sam z Bogiem, dz. cyt., s. 136.

${ }^{132}$ Por. J. Leclercq, Sam na sam z Bogiem, dz. cyt., s. 136. 
jeszcze niedoskonałego, którego typ psychiczny w ten sposób najnaturalniej wyraża się przed Bogiem, lecz można też tą nazwą określać o wiele doskonalszą formę modlitwy ludzi, którzy przez stopniowe uproszczenia swego wewnętrznego życia doszli do syntetycznego spojrzenia, po prostu trwającego przed Bogiem. Przez „trwanie przed Bogiem” można również rozumieć jeszcze wyższy stopień modlitwy, a mianowicie początek kontemplacji wlanej ${ }^{133}$. Kierownikom duchowym o. Rostworowski zaleca, aby nie utrzymywali osób w tym trwaniu przed Bogiem, jeżeli to trwanie jest tylko iluzją wyobraźni, jeżeli dusza jest w próżni, a tylko jej się wydaje, że trwa w Bożej obecności, ponieważ ogołocenie się ze wszystkich myśli i wyobrażeń nie powoduje automatycznie zjednoczenia z Bogiem. Sztucznie spowodowana próżnia jest tylko próżnią i nicością, i dusza wcale się w tej sytuacji nie modli, tylko po prostu nic nie robi ${ }^{134}$. Należy przyjąć te wskazówki z uwagą, ponieważ wypowiedział je człowiek sam doświadczony w modlitwie najpierw jako benedyktyn, a potem jako kameduła.

\section{Sugestie dotyczące formacji do życia pustelniczego i jego realizacji jako indywidualnej formy życia konsekrowanego}

Pustelnikiem może zostać osoba, która zdecyduje się na życie sam na sam z Bogiem i której wystarczy, by być „uczoną przez Boga”. Do tego dochodzi odsunięcie się od świata i zachowanie milczenia.

Kodeks prawa kanonicznego nie wypowiada się na temat formacji osób prowadzących życie konsekrowane w indywidualnej formie. Analogicznie do instytutów życia konsekrowanego należałoby przyjąć, iż przed ślubami wieczystymi pustelników potrzebny jest okres ślubów czasowych oraz przygotowanie, które w zakonie nazywa się nowicjatem ${ }^{135}$.

W aneksie do wskazań duszpasterskich na stronie internetowej Podkomisji KEP ds. INŻK w zakładce dotyczącej pustelników mowa jest o formacji początkowej, która składa się z dwóch etapó $w^{136}$. Etap pierwszy dotyczy wiernych świeckich i trwa maksymalnie pięć lat. Kandydat pozostaje w swoim środowisku życia, realizuje formację ludzką, duchową i intelektualną oraz organizuje

${ }^{133}$ Por. P. Rostworowski, Kierownictwo duchowe. Kilka zasad i wskazówek, Tyniec-Kraków 2012, s. 86-87.

${ }^{134}$ Por. P. Rostworowski, Kierownictwo duchowe..., dz. cyt., s. 89.

${ }^{135}$ Zob. KPK, kan. 641-661.

${ }^{136}$ Por. ks. H. Śmiarowski, Niektóre wskazania duszpasterskie..., dz. cyt. 
miejsce na pustelnię $e^{137}$. Etap drugi dotyczy świeckich i duchownych, trwa także pięć lat. Kandydat przeżywa ten czas w swojej pustelni, jednakże bez więzów kanonicznych, opracowując swój statut osobowy ${ }^{138}$.

Formacja kandydata obejmuje sferę duchową, teologiczną i praktyczną. Gdy chodzi o formację pustelników, ma ona charakter indywidualny, bowiem mało jest osób rozeznających to powołanie, ale może być połączona $\mathrm{z}$ formacją kandydatów do innych indywidualnych form życia konsekrowanego. Trudno byłoby w diecezji organizować studia dzienne czy zaoczne specjalnie dla pustelników, ale warto zastanowić się nad zorganizowaną formacją osób konsekrowanych. Rzeczywiście wskazane w tym przypadku są studia teologiczne, ale może nie dla wszystkich potrzebne są studia magisterskie. Warto wykorzystać do stałej formacji osób konsekrowanych oraz świeckich posługujących w diecezji (nadzwyczajni szafarze Eucharystii, organiści), Studium Duchowości Chrześcijańskiej, jeżeli takie istnieje lub powołać Centrum Formacji Chrześcijańskiej. Zwykle Studium Duchowości Chrześcijańskiej pomyślane jest w ten sposób, że uczestnicy korzystają z zajęć przez trzy lata, otrzymują dyplom i odchodzą. Można by rozszerzyć studium o formację permanentną $\mathrm{w}$ ten sposób, że osoby w niej uczestniczące wybierałyby sobie jakiś dzień, w którym uczestniczyłyby w zajęciach. Warto postarać się o to, by tematyka wykładów była znana z góry. Wykłady w poszczególnych dniach mogą być ułożone tematycznie i dotyczyć np. Biblii, liturgii, jakiegoś zagadnienia czy konkretnej duchowości - monastycznej, karmelitańskiej, jezuickiej, franciszkańskiej, dominikańskiej, duchowości patrystycznej itp.

Dobrze byłoby pomyśleć o tym, by zajęcia w studium można było rozpocząć w każdym miesiącu, a nie tylko w październiku, na początku roku akademickiego. Wtedy nabór można byłoby prowadzić przez cały rok. Słuchacze stali (zdobywający dyplom) chodziliby na wszystkie zajęcia w ciągu trzech lat, a wolni słuchacze tylko na wybrane zajęcia - w zależności od ich potrzeb, i sami ustalaliby sobie częstotliwość. Kandydaci do podjęcia życia konsekrowanego mogliby rozpocząć formację w każdym miesiącu. Byliby oni zobowiązani do uczestniczenia we wszystkich zajęciach formacyjnych aż do uzyskania dyplomu końcowego. Pozostali, czyli przedstawiciele indywidualnych form życia konsekrowanego, nadzwyczajni szafarze, organiści, mogliby wybierać termin swojego spotkania formacyjnego w zależności od zagadnienia poruszanego w danym miesiącu. Kandydaci na pustelników, kandydatki do stanu

${ }^{137}$ Por. ks. H. Śmiarowski, Niektóre wskazania duszpasterskie..., dz. cyt.

${ }^{138}$ Por. ks. H. Śmiarowski, Niektóre wskazania duszpasterskie..., dz. cyt. 
dziewic i stanu wdów chodziliby na wszystkie zajęcia w ramach swojej formacji początkowej (uzyskiwaliby dyplom), w późniejszym czasie mogliby uczestniczyć w zajęciach w ramach swojej formacji stałej. Ta możliwość dotyczyłaby również pustelników.

W ramach zajęć można prowadzić zarówno formację intelektualną, duchową, jak i praktyczną. Ta ostatnia wymagałaby podziału na określone grupy uczestników. W ciągu dnia na początku miałyby miejsce wykłady, potem wprowadzenie do medytacji albo wprowadzenie do spotkań biblijnych w małych grupach, potem czas pustyni (na własną modlitwę) albo czas spotkań w małych grupach czy możliwość skorzystania z kierownictwa duchowego, na końcu msza święta. Blok „formacji duchowej” mogliby prowadzić zamiennie księża odpowiedzialni za poszczególne formy życia konsekrowanego w diecezji lub też jakiś zaproszony gość, który w danym dniu prowadziłby wykłady w ramach „bloku intelektualnego”. Formacja praktyczna mogłaby być prowadzona w formie warsztatów w odrębne dni.

Na stronie Podkomisji KEP ds. IFŻK podano, że formacja duchowa pustelników koncentruje się wokół Eucharystii i Pisma Świętego, w szczególności Księgi Psalmów ${ }^{139}$. Jest w tym niekonsekwencja, gdy chodzi o Księgę Psalmów, ponieważ później pustelnikowi zaleca się odmawianie z liturgii godzin tylko jutrzni i nieszporó ${ }^{140}$. Nie ma żadnych przeszkód, by pustelnik odmawiał całą liturgię godzin, a ponadto jeszcze psalmodię spoza liturgii. Gdy chodzi o duchowość eucharystyczną w odniesieniu do świeckich pustelników, to była już o tym mowa powyżej. W przypadku formacji duchowej dziewic i wdów nie ma przeszkód, by formacja ta koncentrowała się wokół Eucharystii i Pisma Świętego.

Formacja teologiczna pustelników, nazywana później we wspomnianych wskazaniach intelektualną, obejmuje określone studium biblijne, patrystyczne, liturgiczne, sakramentologii, dokumentów Magisterium Kościoła powszechnego, jak i partykularnego. Odnosi się również do tematów związanych z różnymi typami duchowości w Kościele, tradycją ojców pustyni, historią życia pustelniczego, regułami zakonnymi ${ }^{141}$. Formacja ta, według wskazań, mogłaby się realizować w formie studiów dziennych, zaocznych lub korespondencyjnych. Najbardziej wskazane byłoby odbycie studiów teologicznych ${ }^{142}$.

\footnotetext{
${ }^{139}$ Por. ks. H. Śmiarowski, Niektóre wskazania duszpasterskie..., dz. cyt.

${ }^{140}$ Por. ks. H. Śmiarowski, Niektóre wskazania duszpasterskie..., dz. cyt.

${ }^{141}$ Por. ks. H. Śmiarowski, Niektóre wskazania duszpasterskie..., dz. cyt.

${ }^{142}$ Por. ks. H. Śmiarowski, Niektóre wskazania duszpasterskie..., dz. cyt.
} 
Gdy chodzi o zakres formacji intelektualnej dla kandydatów na pustelników, najbardziej przydatne wydaje się studium biblijne i patrystyczne oraz tematy związane $\mathrm{z}$ tradycją ojców pustyni, historią życia pustelniczego i regułami zakonnymi, zwłaszcza monastycznymi. Studium liturgiczne, sakramentologii oraz dokumentów Magisterium Kościoła powszechnego, jak i partykularnego, jest potrzebne w minimalnym zakresie wszystkim wiernym, ale nie jest charakterystyczne dla życia pustelniczego. Odnosi się to również do tematów związanych z różnymi typami duchowości w Kościele. Pustelnik ma już określoną duchowość - jest to duchowość pustelnicza. W przypadku kandydatek do stanu dziewic i stanu wdów formacja teologiczna może obejmować określone studium biblijne, patrystyczne, liturgiczne, sakramentologii, dokumentów Magisterium Kościoła powszechnego, jak i partykularnego oraz odnosić się do tematów związanych z różnymi typami duchowości w Kościele.

Formacja praktyczna pustelników powinna zmierzać do wyuczenia zawodu, przydatnego w życiu pustelniczym lub udoskonalenia posiadanych już umiejętności praktycznych ${ }^{143}$. Formacja praktyczna dziewic i wdów związana jest z wykonywanym przez nich zawodem i środowiskiem życiowym lub wspólnotą parafialną. Jej celem jest przygotowanie konsekrowanych do pełnienia dzieł miłosierdzia lub głoszenia słowa Bożego w zakresie możliwym dla osób świeckich w Kościele partykularnym.

We wskazaniach podano, że pustelnik ma do końca życia kontynuować swoją formację duchową ${ }^{144}$. Wydaje się, że również formacja teologiczna (intelektualna) oraz formacja praktyczna mogłaby mieć charakter permanentny, tak jak ma to miejsce w innych formach życia konsekrowanego.

Gdy chodzi o formację początkową pustelników dokonano różnicy między świeckimi a duchownymi. Jednakże należałoby przyjrzeć się samym świeckim. Być może do życia pustelniczego zgłosi się kandydat dojrzały, po studiach teologicznych, mający doświadczenie w życiu modlitwy. Warto już na pierwszym etapie dać mu możliwość „sprawdzenia się” w życiu pustelniczym, skonfrontowania wyobrażeń z rzeczywistością. We wskazaniach stawia się kandydatowi wymóg ukończenia 35 lat do rozpoczęcia formacji. Gdy dojdzie do tego pierwszy etap formacji początkowej, trwający pięć lat, kandydat dopiero w wieku 40 lat ma możliwość podjęcia życia pustelniczego. Wskazane byłoby, aby na początku formacji kandydat miał możliwość

${ }^{143}$ Por. ks. H. Śmiarowski, Niektóre wskazania duszpasterskie..., dz. cyt.

${ }^{144}$ Por. ks. H. Śmiarowski, Niektóre wskazania duszpasterskie..., dz. cyt. 
doświadczenia życia pustelniczego, by mógł poznać swoje predyspozycje do takiego życia i by wiedział, czy może podjąć taką formację zmierzającą do ukierunkowania jego życia na stałe w powołaniu pustelniczym. Dobrze byłoby, gdyby formacja początkowa nie była ograniczona w czasie. Być może znajdą się osoby, które będą chciały żyć życiem pustelniczym, ale bez więzów kanonicznych, którym warto ze strony diecezji zapewnić opiekę duchową i formację. Wśród ojców Kościoła spotykamy osoby, które czasowo żyły duchowością pustelniczą i niekiedy powracały ze świata na jakiś czas do pustelni. Współcześnie również dla niektórych osób taki sposób życia duchowego może być najkorzystniejszy.

\section{Przesłanki wynikające z duchowości pustelniczej dla innych indywidualnych form życia konsekrowanego}

Duchowość pustelnicza charakteryzuje się życiem sam na sam z Bogiem, w którym to Bóg jest Tym, któremu oddaje się swój czas, swoje myśli, swoją modlitwę. Pustelnik jest „uczony przez Boga”. Do tego dochodzi brak przywiązania do rzeczy materialnych, życie w prostocie, ubóstwie i ciszy oraz zachowanie milczenia. Okres takiej pustyni pożyteczny jest dla każdej osoby oddanej Bogu. Czas pustyni może być wskazany podczas formacji początkowej dla kandydatek do stanu dziewic i stanu wdów. Byłaby to możliwość czasowego odsunięcia się od świata, by w milczeniu odosobnienia być „pouczoną przez Boga” odnośnie do własnego życia.

Czas przeznaczony tylko dla Boga, by z Nim być sam na sam, może się realizować $\mathrm{w}$ formie dnia pustyni lub tygodnia pustyni. Może być przeżywany jako pustynia $\mathrm{w}$ mieście, nie wykluczając pozostawania $\mathrm{w}$ miejscu zamieszkania. Chodzi w tym przypadku o odsunięcie się od świata, czyli od wiadomości i od kontaktu $\mathrm{z}$ innymi. Czas pustyni to czas bez telefonu, komputera, rozmów. To także czas, w którym nie są podejmowane modlitwy wstawiennicze. Jedynym wyjątkiem jest modlitwa wstawiennicza w liturgii eucharystycznej lub liturgii godzin. Warto zaznaczyć, że czas pustyni, wyodrębniony w ciągu dnia i ograniczony do kilku godzin, może być pożyteczny dla wszystkich. Z przekazów ewangelicznych wiadomo, że Jezus praktykował taką formę modlitwy ${ }^{145}$.

Dzień pustyni, czyli spędzenie w samotności jednego dnia w tygodniu, wyłączając się od innych zajęć, praktykowany jest w Jerozolimskich Wspólnotach

${ }^{145}$ Zob. Mk 1, 35; 6, 46; Mt 14, 23; Łk 5, 16. 
Monastycznych ${ }^{146}$. W regule życia przy omawianiu milczenia czytamy zapis, aby zachowywać zwłaszcza cotygodniowy dzień pustyni i przeżywać go tak, jak Chrystus, który lubił odchodzić na ustronia i prowadził tam swoich uczniów ${ }^{147}$. Autor reguły pisze: „Bóg cię zaprasza, aby w tych dniach samotności oczarować cię, wyprowadzić na pustynię i w ciszy mówić do twego serca $(\mathrm{Oz} 2,16){ }^{\text {"148 }}$. Dziewice lub wdowy konsekrowane mogą organizować sobie dzień pustyni w zależności od życiowych uwarunkowań raz w tygodniu, raz w miesiącu lub raz na kwartał. W tych dniach samotności, sam na sam z Bogiem, mogą wyciszyć się, aby usłyszeć głos Oblubieńca.

Tydzień pustyni może być organizowany raz w roku jako indywidualne rekolekcje. Wówczas w milczeniu, ograniczając się do niewielu słów nawet podczas modlitwy, można doświadczyć obecności Boga.

\section{Uwagi końcowe}

Z niniejszych rozważań wynika kilka kwestii dotyczących duchowości pustelniczej oraz prowadzenia życia pustelniczego w ramach indywidualnych form życia konsekrowanego, nad którymi warto podjąć naukową refleksję.

Pierwsza kwestia dotyczy sprecyzowania duchowości pustelniczej. Należy określić dokładnie specyfikę życia pustelniczego i realizacji w nim życia kontemplacyjnego. Wydaje się, że nie można przenosić automatycznie rozwiązań $\mathrm{z}$ zakonów klauzurowych ani też łączyć pustelnictwa $\mathrm{z}$ duszpasterstwem. Ze względu na indywidualny charakter powołania pustelniczego mogą wyróżnić się różne charyzmaty w tym względzie, jednakże nad wszelkimi odstępstwami od normy należy się dogłębnie zastanowić.

Druga kwestia dotyczy organizacji życia pustelniczego oraz określenia warunków zewnętrznych oraz wewnętrznych, w których życie pustelnicze może być prowadzone. Należy zaznaczyć, że życie pustelnika może przebiegać etapami, od mniejszego do większego odsunięcia się od świata aż do powrotu do świata w przypadku choroby i starości. Śluby pustelnicze dotyczą czystości, ubóstwa i posłuszeństwa, a nie zachowania konkretnej reguły, która w ciągu życia może ulegać zmianom. Biskup dopuszcza do formacji, przyjmuje śluby

${ }^{146}$ Por. P. M. Delfieux, Źródło na pustyni miast. Reguła życia Jerozolimskich Wspólnot Monastycznych, przekł. i wprowadzenie K. Strzelecka, Warszawa 1991, nr 38, s. 52; J. M. Popławski, Eremityzm, w: Leksykon duchowości katolickiej, dz. cyt., s. 249.

${ }^{147}$ Por. P. M. Delfieux, Źródło na pustyni miast, dz. cyt., nr 38, s. 52.

${ }^{148}$ P. M. Delfieux, Źródło na pustyni miast, dz. cyt., nr 38, s. 52. 
pustelnicze i zatwierdza regułę życia pustelnika. Śluby są trwałe, natomiast reguła życia może ulegać modyfikacjom.

Trzecia kwestia dotyczy formacji do życia pustelniczego. Warto zorganizować w diecezji trwałe struktury zajmujące się formacją duchową, teologiczną i praktyczną wszystkich kandydatów decydujących się na podjęcie indywidualnej formy życia konsekrowanego w pewnych elementach wspólną, a w innych zróżnicowaną w zależności od konkretnego powołania.

\section{ABstrakt}

Niniejszy artykuł podejmuje zagadnienie pustelników jako przedstawicieli indywidualnej formy życia konsekrowanego. Oparto się na dostępnych źródłach dotyczących życia pustelniczego, zwłaszcza w jego okresie początkowym, oraz na opracowaniach. Postawiono pytania odnoszące się do specyfiki życia pustelniczego i duchowości pustelników. Scharakteryzowano życie pustelnicze w oparciu o współczesny kodeks prawa kanonicznego. Podjęto zagadnienie tradycyjnych zajęć pustelników. Na końcu podano sugestie dotyczące formacji do życia pustelniczego oraz przesłanki wynikające z duchowości pustelniczej dla dziewic i wdów.

\section{SŁOWA KLUCZOWE}

pustelnik, duchowość pustelnicza, indywidualne formy życia konsekrowanego

\section{ABstract}

\section{Hermits as an individual form of consecrated life}

This article takes up the idea of hermits as an individual form of consecrated life. It is based on the available sources concerning the life of a hermit, especially in the initial period, and on publications. Raised questions are related to the specifics of hermit life and spirituality of the hermits. The hermit characteristics is made on the basis of the modern Code of Canon Law. It takes up the issue of the traditional activities of hermits. At the end there are suggestions for the formation for the life of a hermit and the premises resulting from the hermit spirituality for virgins and widows.

\section{KEYWORDS}

hermit, hermit spirituality, individual forms of consecrated life 


\section{BIBLIOGRAFIA}

Altaner B., Stuiber A., Patrologia. Życie, pisma i nauka Ojców Kościoła, przeł. P. Pachciarek, Warszawa 1990.

Apoftegmaty Ojców pustyni, t. 2, Kolekcja systematyczna, przekł. M. Kozera, Kraków-Tyniec 1995.

Bartoszewski G., Prawne podstawy dla indywidualnych form życia konsekrowanego, http://www.zyciezakonne.pl/dokumenty/referaty-konferencje-artykuly/zagadnienia-prawne/bartoszewski-g-ofmcap-prawne-podstawy-dla-indywidualnych-form-zycia-konsekrowanego-30254/ (13.01.2017).

Bruna od Maryi, Eremityzm. Wprowadzenie w duchowość i praktykę życia pustelniczego, Warszawa-Częstochowa 2016.

Campenhausen H. von, Ojcowie Kościoła, tłum. K. Wierszyłowski, Warszawa 1998.

Chmielewski M., Pokuta, w: Leksykon duchowości katolickiej, red. M. Chmielewski, Lublin-Kraków 2002, s. 649.

Chrapkowski A., Krzywda J., Wroceński J., Zubert B. W., Komentarz do Kodeksu Prawa Kanonicznego, t. II/2: Księga II: Lud Boży. Część III: Instytuty życia konsekrowanego i stowarzyszenia życia apostolskiego, red. naukowy J. Krukowski, Poznań 2006.

Daniélou J., Marrou H. I., Historia Kościoła, t. 1: Od początków do roku 6oo, przeł. M. Tarnowska, Warszawa 1984.

Daniel-Rops [H.], Kościót pierwszych wieków, przeł. K. Ostrowska, Warszawa 1997.

Daniluk M., Klauza K., Podręczna encyklopedia instytutów życia konsekrowanego, Lublin 1994.

Delfieux P. M., Źródło na pustyni miast. Reguła życia Jerozolimskich Wspólnot Monastycznych, przekł. i wprowadzenie K. Strzelecka, Warszawa 1991.

Dembicki J. A. OSPPE, W Grocie Świętego Pawła I Pustelnika, http://www.jasnagora. com/wydarzenie-2398 (29.12.2016).

Drączkowski F., Patrologia, Pelplin-Lublin 1999.

Galiński P., Kim powinien być mnich? Powrót do źródeł... O duchowości monastycznej [cz. 3], http://ps-po.pl/2014/o3/o1/kim-powinien-byc-mnich-powrot-do-zrodel-o-duchowosci-monastycznej-cz-3/ (4.11.2016).

Grzywaczewski J., Porozmawiajmy o początkach chrześcijaństwa, Warszawa 1999.

Hamman A. G., Życie codziennie w Afryce Północnej w czasach św. Augustyna, przekł. M. Stafiej-Wróblewska, E. Sieradzińska, Warszawa 1989.

Historia mnichów w Egipcie, przekł. E. Dąbrowska, wstęp E. Wipszycka, R. Wiśniewski, Kraków-Tyniec 2011.

http://brewiarz.pl/czytelnia/swieci/12-o2c.php3 (29.12.2016). 
http://brewiarz.pl/i_17/1601w4/czyt.php3 (16.01.2017).

http://www.ifzk.episkopat.pl/sympozjum_2016-pustelnicy.php (11.01.2017).

http://www.paulini.pl/pl/14,Charyzmat-Zakonu (10.11.2016).

http://www.swcharbel.webs.com/ (29.12.2016).

Jan Paweł II, List apostolski Orientalne lumen.

Jan Paweł II, Adhortacja apostolska o życiu konsekrowanym i jego misji w Kościele

i w świecie Vita consecrata, Częstochowa 1996.

Kaczmarek T., Ideały życia pustelniczego w IV wieku, w: Wczesnochrześcijańska asceza.

Zagadnienia wybrane, red. F. Drączkowski, J. Pałucki, Lublin 1993, s. 59-71.

Kalendarz liturgiczny archidiecezji częstochowskiej na rok 2017, oprac. K. Bełkot,

Częstochowa 2016.

Katechizm Kościoła Katolickiego, Poznań 1994.

Kodeks prawa kanonicznego. Przekład polski zatwierdzony przez Konferencję Episkopatu, Poznań 1984.

Leclercq J., Humanista-eremita. Błogosławiony Paweł Giustiniani (1476-1528), przekł.

E. Buszewicz, Kraków-Tyniec 2014.

Leclercq J., Sam na sam z Bogiem. Życie pustelnicze na podstawie doktryny błogosławionego Pawła Giustinianiego, przekł. E. Buszewicz, Kraków-Tyniec 2014.

Leclercq J., U źródeł duchowości Zachodu. Etapy rozwoju i elementy stałe, przekł. S. Sztuka, Kraków-Tyniec 2009.

Leidi L., Tożsamość indywidualnych form życia konsekrowanego w Kościele, http:// www.konsekrowane.org/dziewice/konf.php (22.11.2016).

Manteuffel T., Historia powszechna. Średniowiecze, Warszawa 1968.

Mnisi nie tylko ci święci... Z prof. Ewa Wipszycka o pierwszych mnichach na pustyni egipskiej rozmawia Szymon Hizycki osB, Kraków-Tyniec 2007.

Pierwsza Księga Starców. Gerontikon, przekł. M. Borkowska, wstęp, opracowanie i redakcja M. Starowieyski, Kraków 1992.

Pieszczoch S., Patrologia, t. 1: Działalność Ojców, Gniezno 1994.

Popławski J. M., Eremityzm, w: Leksykon duchowości katolickiej, red. M. Chmielewski, Lublin-Kraków 2002, s. 249.

Powołana do pustelni. Z s. Hiobą Kamińską rozmawia Małgorzata Kołodziejczyk, http://www.mojepowolanie.pl/3231,a,powolana-do-pustelni.htm (3.01.2017).

Rostworowski P., Kierownictwo duchowe. Kilka zasad i wskazówek, Tyniec-Kraków 2012. S. Athanasii, Vita S. Antonii, in: S.P.N. Athanasii archiepiscopi Alexandrini Opera omnia quae exstant, tomus secundus, accurante et recognoscente J.-P. Migne, Parisiis 1857, col. 835-976 (Patrologiae Cursus Completus. Series Graeca, 26), http:// patristica.net/graeca/\#to26 (23.12.2016); tekst polski: Św. Atanazy Aleksandryjski, Żywot świętego Antoniego, Św. Atanazy Aleksandryjski, Żywot świętego Antoniego, 
w: Św. Atanazy Aleksandryjski, Żywot świętego Antoniego; Św. Antoni Pustelnik, Pisma, przeł. Z. Brzostowska i in., wstępami i komentarzami opatrzyła E. Wipszycka, Warszawa 1987, s. 55-111.

S. Aurelii Augustini, De opere monachorum, in: Sancti Aurelii Augustini Hipponensis episcopi Opera omnia, tomus sextus, accurante J.-P. Migne, Parisiis 1841, col. 569, 578 (Patrologiae Cursus Completus. Series Latina, 40), http://patristica.net/latina/\#to4o (22.11.2016).

S. Eusebii Hieronymi, Vita S. Pauli primi eremita, in: S. Eusebii Hieronymi Stridonensis presbyteri Opera omnia, tomi secundus et tertius, accurante J.-P. Migne, Parisiis 1845, col. 17-28 (Patrologiae Cursus Completus. Series Latina, 23), http:// patristica.net/latina/ (27.12.2016); tekst polski: Św. Hieronim, Żywot św. Pawła Pierwszego Pustelnika, tłum. W. Szołdrski, w: J. S. Płatek, Początki Zakonu św. Pawła Pierwszego Pustelnika. Źródła duchowości Zakonu św. Pawła Pierwszego Pustelnika, Częstochowa 1989, s. 32-41.

Sancti Patris nostri Athanasii archiepiscopi Alexandrini ad Marcellinum in interpretationem psalmorum, in: S.P.N. Athanasii archiepiscopi Alexandrini Opera omnia quae exstant, tomus tertius, accurante et recognoscente J.-P. Migne, Parisiis 1857, col. 11-20 (Patrologiae Cursus Completus. Series Graeca, 27), http://patristica.net/graeca/\#to26 (16.01.2017); tekst polski: przekł. A. Tronina, „Vox Patrum” 10 (1990) t. 18, s. 310-315.

Simon M., Cywilizacja wczesnego chrześcijaństwa I-IV w., przeł. E. Bękowska, Warszawa 1992.

Sławiński J., Hagiografia, w: Słownik terminów literackich, red. J. Sławiński, Wrocław-Warszawa 1976, s. 149.

Stypułkowska B., Indywidualne formy życia konsekrowanego w kontekście roku życia konsekrowanego, „Częstochowskie Studia Teologiczne” 43 (2015), s. 117-145.

Stypułkowska B., Perspektywy dla dziewic konsekrowanych żyjących w świecie wynikające z duchowości monastycznej, „Analecta Cracoviensia” 48 (2016), s. 195-222. Śmiarowski H., Niektóre wskazania duszpasterskie dotyczace konsekrowanych pustelników i pustelnic, http://www.ifzk.episkopat.pl/dokumenty/3.4.3-ove-artykul-aneks. pdf (13.01.2017). http://www.quies.org/DiscerningEremiticalLifefromCongCL.pdf (13.01.2017).

Śmiarowski H., Pustelnicza droga, http://www.ifzk.episkopat.pl/dokumenty/pustelnicza_droga.pdf (12.11.2016).

Św. Augustyn, Wyznania, tłumaczył oraz wstępem i kalendarium opatrzył Z. Kubiak, Kraków 1994.

Św. Bazyli Wielki, Pisma ascetyczne, t. 1, przekład i opracowanie J. Naumowicz, Kraków-Tyniec 1994. 
Św. Bazyli Wielki, Pisma ascetyczne, t. 2: Reguły dłuższe. Reguły krótsze, przekł. i oprac. J. Naumowicz, Tyniec-Kraków 1995.

Św. Grzegorz z Nazjanzu, Mowa 21. Pochwała Wielkiego Atanazego, biskupa Aleksandrii ( $P G, t$. 35, k. 1081-1128), w: Święty Grzegorz z Nazjanzu, Mowy wybrane, pr. zbior., Warszawa 1967, s. 226-243.

Tronina A., Wstęp, w: Św. Atanazy, List do Marcelina o interpretacji psalmów, przekł. A Tronina, „Vox Patrum” 10 (1990) t. 18, s. 303-309.

Voillaume R., Echa Nazaretu, Kraków 1991.

Zachodnie reguły monastyczne, przekł. K. Bielawski i in., wstępy J. Naumowicz i in., oprac. T. Dekert i in., red. M. Starowieyski, Tyniec-Kraków 2013.

Zubert B. W., Komentarz do Kodeksu Prawa Kanonicznego z 1983 roku. Księga II: Lud Boży. Część III: Instytuty życia konsekrowanego i stowarzyszenia życia apostolskiego, Lublin 1990. 